


\section{Cleaning and disinfection in the Dutch red meat and game meat supply chains}

Y. Hoffmans, J.L. Banach, E.D. van Asselt, E.F. Hoek - van den Hil

This research has been carried out by Wageningen Food Safety Research, institute within the legal entity Wageningen Research Foundation funded by the Netherlands Food and Consumer Product Safety Authority (NVWA) (project number WOT-02-002-004).

Wageningen, December 2020

WFSR report 2020.021 
Hoffmans, Y., Banach J.L., Asselt van E.D., E.F. Hoek - van den Hil, 2020. Cleaning and disinfection in the Dutch red meat and game meat supply chains. Wageningen, Wageningen Food Safety Research, WFSR report 2020.021. 56 pp.; 3 fig.; 8 tab.; 42 ref.

Project number: 1297378001

Project title: Cleaning Disinfection

Project leader: Elise F. Hoek-van den Hil

This report can be downloaded for free at https://doi.org/10.18174/537329 or at www.wur.eu/foodsafety-research (under WFSR publications).

(C) 2020 Wageningen Food Safety Research, institute within the legal entity Wageningen Research Foundation. Hereinafter referred to as WFSR.

The client is allowed to publish or distribute the full report to third parties. Without prior written permission from WFSR it is not allowed to:

a) publish parts of this report;

b) use this report or title of this report in conducting legal procedures, for advertising, acquisition or other commercial purposes;

c) use the name of WFSR other than as the author of this report.

P.O. Box 230, 6700 AE Wageningen, The Netherlands, T +31 (0)317 4802 56, E info.wfsr@wur.nl, www.wur.eu/food-safety-research. WFSR is part of Wageningen University \& Research.

This report from WFSR has been produced with the utmost care. However, WFSR does not accept liability for any claims based on the contents of this report.

WFSR report 2020.021

Distribution list:

- Dr. M.W. den Braver

- Dr. S.M. Schrap

- Dr. T.H.M. Sijm 


\section{Contents}

$\begin{array}{ll}\text { Summary } & 5\end{array}$

1

$\begin{array}{ll}\text { Introduction } & 7\end{array}$

2

$\begin{array}{ll}\text { Methods and Materials } & 8\end{array}$

2.1 Demarcation $\quad 8$

$\begin{array}{lll}2.2 & \text { Authorised disinfection products } & 8\end{array}$

$\begin{array}{lll}2.3 & \text { Literature search } & 8\end{array}$

2.4 Questionnaires and interviews 9

2.5 Monitoring data $\quad 9$

3.1 Authorised disinfection products $\quad 11$

3.1.1 Ctgb database $\quad 11$

3.1.2 Conclusion on authorised disinfection products 14

3.2 Cleaning and disinfection products applied in red meat chain $\quad 15$

3.2.1 Product uses according to publications found in the Google search $\quad 15$

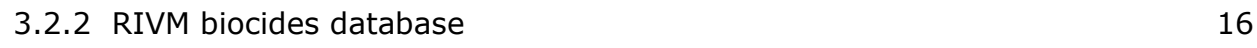

3.2.3 Conclusions on the use of cleaning and disinfection products based on literature

3.3 Hygiene protocols and procedures in de red meat chain $\quad 19$

3.3.1 Primary production 19

$\begin{array}{ll}3.3 .2 \text { Transport } & 19\end{array}$

3.3.3 Slaughterhouse $\quad 20$

3.3.4 Cold storage $\quad 21$

$\begin{array}{ll}3.3 .5 \text { Processing } & 21\end{array}$

3.3.6 Suppliers of cleaning and disinfection agents $\quad 22$

3.3.7 Conclusions based on hygiene protocols $\quad 22$

3.4 Challenges related to cleaning and disinfection in the red meat chain 23

3.5 Results of interviews and questionnaires for the red meat chain 24

3.5.1 Active ingredients used for cleaning and disinfection $\quad 24$

3.5.2 Cleaning and disinfection in practice $\quad 27$

3.5.3 Supervising body (NVWA) 35

3.5.4 Conclusions based on interviews and questionnaires 36

3.6 Decontamination in the red meat chain 38

3.7 Residues found in red meat products based on Dutch monitoring data 39

3.8 Cleaning and disinfection in the game meat chain 40

3.8.1 Hygiene protocols and procedures $\quad 40$

3.8.2 Results of interviews game meat chain $\quad 40$

3.8.3 Conclusions on the game meat chain 43

4 Discussion $\quad 44$

$4.1 \quad$ Authorised biocidal products 44

4.2 Active ingredients in cleaning and disinfection products 44

4.3 Hygiene protocols and cleaning and disinfection practices 44

$\begin{array}{lll}4.4 & \text { Residues } & 45\end{array}$

$5 \quad$ Main conclusions and recommendations $\quad 46$

$\begin{array}{lll}5.1 & \text { Conclusions } & 46\end{array}$

5.2 Recommendations $\quad 46$ 
Annex 1 Questionnaires red meat chain

Annex 2 Interviews red meat chain 52

Annex 3 Questionnaire inspectors 53

Annex 4 Interviews game meat chain 54

Annex 5 Statement of game hygiene for large game animals 55 


\title{
Summary
}

\begin{abstract}
Aim of the study
Cleaning and disinfection agents are used in several steps in the red meat and game meat supply chains to ensure product quality, product safety, and to enhance shelf-life. The aim of this research is to investigate by literature study, questionnaires and interviews, which cleaning agents and disinfectants are authorised to be used and where and how they are used in the different stages of the Dutch red meat supply chain. Furthermore, knowledge obtained from this study is used to investigate the use of cleaning and disinfection agents in the Dutch game meat chain.
\end{abstract}

\section{Hygiene protocols and practices}

Stakeholders in both supply chains indicated that they work according to hygiene protocols as defined by branch organisations and the Netherlands Food and Consumer Product Safety Authority (NVWA). Procedures for cleaning and disinfection are laid down in protocols and/or Hazard Analysis Critical Control Point (HACCP) plans. The number of different cleaning and disinfection agents used by hunters and at farms is lower than in other parts of the food chains. In the transport part of the red meat chain, sometimes resources to correctly perform cleaning and disinfection are limited. How cleaning and disinfection agents should be applied is described in specification sheets and on the labels of the cleaning and disinfection products. Interviews with various experts showed that there is less knowledge about protocols and regulation related to cleaning and disinfection in some smaller companies compared to larger companies. Insufficient cleaning and disinfection procedures could occur in all parts of the chain due to insufficient knowledge or time limitations, which could lead to residues in food products.

\section{Main active compounds in cleaning and disinfection products}

The main authorised, active ingredients in disinfectant products that can be used as product type 1, 3 or 4 (PT1, PT3 or PT4) and are relevant product types for the red meat and game meat chains, include alcohol-based compounds (mainly ethanol and propanol); chlorine-based compounds (among others sodium hypochlorite); hydrogen peroxide (in combination with peracetic acid); quaternary ammonium compounds (quats) (mainly didecyldimethylammonium chloride (DDAC) and alkyl (C12-16) dimethylbenzylammonium chloride); aldehydes (glutaraldehyde, formaldehyde); iodine; and lactic acid.

The active ingredients used for disinfection in the red meat chain, as indicated in the literature, interviews, and questionnaires were all authorised ingredients. Frequently reported used cleaning products or ingredients in the red meat chain in the Netherlands were hand soap, potassium hydroxide, and sodium hydroxide. Similarly, for disinfection agents frequently used ingredients were alcohol-based products, chlorine-based products (mainly sodium hypochlorite), DDAC, hydrogen peroxide and peracetic acid.

In general, cleaning and disinfection procedures and agents used during slaughter, storage and processing of game meat are comparable to those used for red meat.

\section{Residues and monitoring}

The monitoring on residues of cleaning and disinfection agents and inspections on cleaning and disinfection procedures are limited in the Netherlands. Data of slaughterhouses (2017-2018) show that no quats (benzalkonium chloride (BAC) and DDAC) were found in red meat products. Monitoring of the active ingredients frequently used in the red meat and game meat chains, and could therefore be present in food products, should be increased; these are quats and by-products formed by the use of chlorine-containing products. 


\section{Introduction}

Cleaning and disinfection agents are used in several steps in the food supply chain to ensure product quality and product safety and to enhance shelf-life. However, the use of cleaning and disinfection agents could potentially result in residues of these agents in the food products. This can occur in different parts of the supply chain. Earlier, we have studied cleaning and disinfection in the poultry, eggs, leafy greens and sprouts supply chains. While in this study, the focus will be on cleaning and disinfection in the red meat and game meat supply chains.

The red meat chain can be divided in three different phases. The primary phase (phase I), where cattle, pigs, goats, and sheep are grown at the farms. The secondary phase (phase II) involves transport, slaughterhouses, cutting plants, and cold storage. This is followed by the tertiary phase (phase III) of trade, processing and consumption. The game meat chain consists of free and farmed game. Furthermore, the chain slightly differs from the red meat chain, because hunters are involved next to farms of farmed game (phase I). For phase II and III, there are specific NVWA approved establishments like slaughterhouses, cutting plants and processing industries that can handle meat of game animals, whereas other parts of the chain are comparable with the red meat chain.

Residues of cleaning and disinfection agents could potentially enter the supply chain via materials, such as cribs, drinking bowls, and floors in the stables, transport crates, materials such as knifes, tables etc. in slaughterhouses and cutting plants, during storage and during further processing. However, it is largely unknown which cleaning and disinfections agents are used in the red meat and game meat chain and if this results in residues in the final food products.

Only chemicals that are registered under Registration, Evaluation, Authorization and restriction of Chemicals (REACH) can be used in cleaning and disinfection products in the European Union (EU). The regulation of disinfectants within the EU is more extensive compared to cleaning agents, as additional safety assessments are explicitly needed for the intended use of the disinfectants (Regulation (EU) No 528/2012 - Biocidal Products Regulation (BPR)). In the Netherlands, the Board for the Authorisation of Plant Protection Products and Biocides (College voor de toelating van gewasbeschermingsmiddelen en biociden - Ctgb) is responsible for the authorisation of disinfectants (Banach 2020).

The aim of this research is to investigate which cleaning agents and disinfectants are authorised to be used and where and how they are used in the different stages of the red meat supply chain.

Furthermore, knowledge obtained from this study is used to study the use of cleaning and disinfection agents in the game meat chain. 


\section{Methods and Materials}

\section{$2.1 \quad$ Demarcation}

Chemical active ingredients in cleaning and disinfection products used in the red meat and game meat chain in the Netherlands were studied. This includes production and processing in the Netherlands, import was not taken into account. The red meat chain includes meat from the following animals: cattle, pigs, horses, goats, and sheep. The game meat chain focussed on farmed large game and ratites and free large game (fallow deer, mint yak, mouflon, ostrich, red deer, roe deer and wild boar). This study was started with the red meat chain; knowledge obtained from the red meat chain is used to study the use of cleaning and disinfection agents in the game meat chain.

\subsection{Authorised disinfection products}

In order to obtain an overview of the authorised disinfection products that may be used in the red meat chain, the authorisation database of the Ctgb was consulted. Ctgb is the appointed authority to approve plant protection products and biocides as described in art. 7 of the Regulation (EU) 528/2012. For the purpose of this research, only biocides are selected, and further selection was focused on Product Type (PT) 1, PT3 and PT4. PT 1 products are biocidal products used for human hygiene purposes, applied on or in contact with human skin or scalps for the primary purpose of disinfecting the skin or scalp. PT3 products are used for veterinary hygiene purposes such as disinfectants, disinfecting soaps, oral or corporal hygiene products for animals. They are used to disinfect the materials and surfaces associated with the housing or transportation of animals. PT4 products are used for the disinfection of equipment, containers, consumption utensils, surfaces or pipework associated with the production, transport, storage or consumption of food or feed for humans and animals. Furthermore, they are used to impregnate materials that may enter into contact with food as specified in the Biocidal Product Regulation ((EU) No 528/2012). With the help of the advanced search engine in the authorisation database, it was possible to insert several search terms on specific animal species. However, applications of biocidal products are not restricted to be used for specific animal species. In some applications, it is described for example in which animal species the biocidal product can be used, and then the animal species can be mentioned. However, this is not done in every application of the biocidal products that may be used in the red meat chain. Therefore, it is not reliable to use a specific animal as search term, since it would not result in all biocidal products that may be used. Finally, a total overview was made of active ingredients as present in authorised PT1, PT3 and PT4 biocidal products.

\subsection{Literature search}

In order to get an overview of cleaning and disinfection agents that are used in the Netherlands, reports of RIVM and NVWA and several magazines related to the food industry and the red meat supply chain, were consulted. Relevant articles were searched by using the advanced search feature in Google using the following search terms: reiniging OR desinfectie AND vlees. The advanced search was conducted in the websites of the following organisations:

- RIVM

- VMT

- Voeding Nu

- Vakblad Voedingsindustrie

- NVWA

- Vleesmagazine

- Vleesplus 
For the websites VMT and Vakblad Voedingsindustrie, the search term "hygiene protocol" was also applied. The search was conducted with a time range between 2010 and (April) 2020 for the date of publication. Additionally, relevant information was searched on the EFSA website using the advanced search engine in Google with the search terms cleaning OR disinfection AND meat. Furthermore, general searches in Google were performed on "hygiene", "reiniging", "desinfectie" and "vlees".

Furthermore, a search in Scopus was performed using the search string: TITLE-ABS-KEY (cleaning OR disinfection) AND TITLE-ABS-KEY (meat) AND TITLE-ABS-KEY ("Dutch" OR "The Netherland*" OR "Netherland*").

Additionally, searches in Google were performed to find specific information related to cleaning and disinfection in the game meat chain (in the Netherlands), using the following search terms (in Dutch and English) "cleaning", "disinfection", "hygiene" or "decontamination" in combination with "game" or "game meat".

\subsection{Questionnaires and interviews}

A predefined questionnaire was established to gain insight into the active ingredients used during cleaning and disinfection in the red meat chain (Annex 1). Separate questionnaires were drafted for: 1. primary production and transport, 2. processing, and 3. suppliers of cleaning and disinfection agents. Some additional questions were added for the interviews (Annex 2). For different parts of the red meat chain, organizations and companies to be contacted were identified using Google, the VMT Voedingsmiddelen Jaarboek 2018, and the NVWA list of approved establishments ${ }^{1}$. Organizations and companies were contacted by email and sent the questionnaire, depending on their expertise, or were interviewed based on the questionnaire.

In total, 136 questionnaires or invitations for interviews were sent in April 2020, of which 8 for primary production, 11 for cleaning and disinfection companies for farms, 15 for transport, 29 for slaughterhouses (15 for small/middle, 14 for large slaughterhouses), 14 for cutting plants, 14 for cold storage, 29 for processing (14 meat products, 15 minced/mechanically separated), 14 for suppliers of cleaning and disinfection agents and 2 concerning general cleaning and disinfection. After two weeks, a reminder was sent to people who did not respond. Interviewees were experts from branch organizations, the NVWA, or large companies involved in different parts of the chain.

Furthermore, via a contact person of the NVWA, a short questionnaire was also send to NVWA inspectors (Annex 3).

In total, 11 invitations for interviews were sent in July 2020 to persons involved in the game meat chain. These included hunters, game farms, slaughterhouses and processing industries that are approved to handle game meat animals. After two weeks, a reminder was sent to people who did not respond. An overview of the questions asked during the interviews for the game meat chain can be found in Annex 4.

\section{$2.5 \quad$ Monitoring data}

Data from the Dutch national monitoring program on chemical contaminants in food and feed were retrieved from the Quality Program for Agricultural Products (chemKAP) database. This database includes data from the Dutch government, including the NVWA, and agribusinesses. ${ }^{2}$ Data were extracted for the following five product groups: animals, animal fats, animal meat products, animal products, and meat and meat products. Data on active ingredients used in cleaning agents and disinfectants were extracted for these compounds (see Table 1), these compounds were selected

\footnotetext{
1 https://english.nvwa.nl/topics/approved-establishments/food-establishments

2 https://chemkap.rivm.nl/
} 
based on the list of Ctgb approved substances. The years for which data on disinfection substances were available from the database were: 2002, 2003, 2017 and 2018.

Table 1 Names of compounds related to cleaning and disinfection agents as extracted from the chemKAP database

\section{Compounds}

Acetic acid

Bromide (inorganic)

Chlorate

Citric acid

Copper oxychloride

Dichloroisocyanuric acid

Didecyldimethylammonium chloride

Didodecyldimethylammonium chloride

Dimethyldioctylammonium chloride

Ethylene dichloride

Formaldehyde

Formetanate hydrochloride

Hydrogen-peroxide

Iodine

Lactic acid

Malic acid

Peracetic acid

Perchlorate

Peroxide

Quaternary ammonium compounds (includes benzalkonium chloride (BAC), didecyldimethylammonium chloride (DDAC), etc.)

Sodium chloride

Trimethylamine hydrochloride 


\section{$3 \quad$ Results}

\subsection{Authorised disinfection products}

\subsubsection{Ctgb database}

In the Netherlands, the Ctgb is responsible for the authorisation of disinfectants. In the previous report on cleaning and disinfection agents, data were extracted from the Ctgb database in June 2018 (Banach 2020). The Ctgb database showed that, as of April 2020, 96 biocidal products are authorised for PT1 (hand hygiene), 240 for PT3 (veterinary use) and 481 for PT4 (use in food processing) (Table 2). These biocidal products include all authorised products and expired authorised products, which are in the phase-out period. These products are authorised to be used in among others the red and game meat chain. In the past two years, three new active ingredients are used in authorised biocidal products. These concern 2-fenoxyethanol, sodium benzoate and tartaric acid. The latter two are used together as mixture in sprays or wipes that may be used for the disinfection of surfaces in food and/or feed companies. The alcohol 2-fenoxyethanol is an active ingredient used in combination with chlorhexidine in a disinfecting soap for the purpose of handwashing, however this authorisation expired in April 2020 (Ctgb 2020).

Table 2 List of active ingredients in authorised biocidal products in the relevant product types (PTs) (Ctgb 2020)

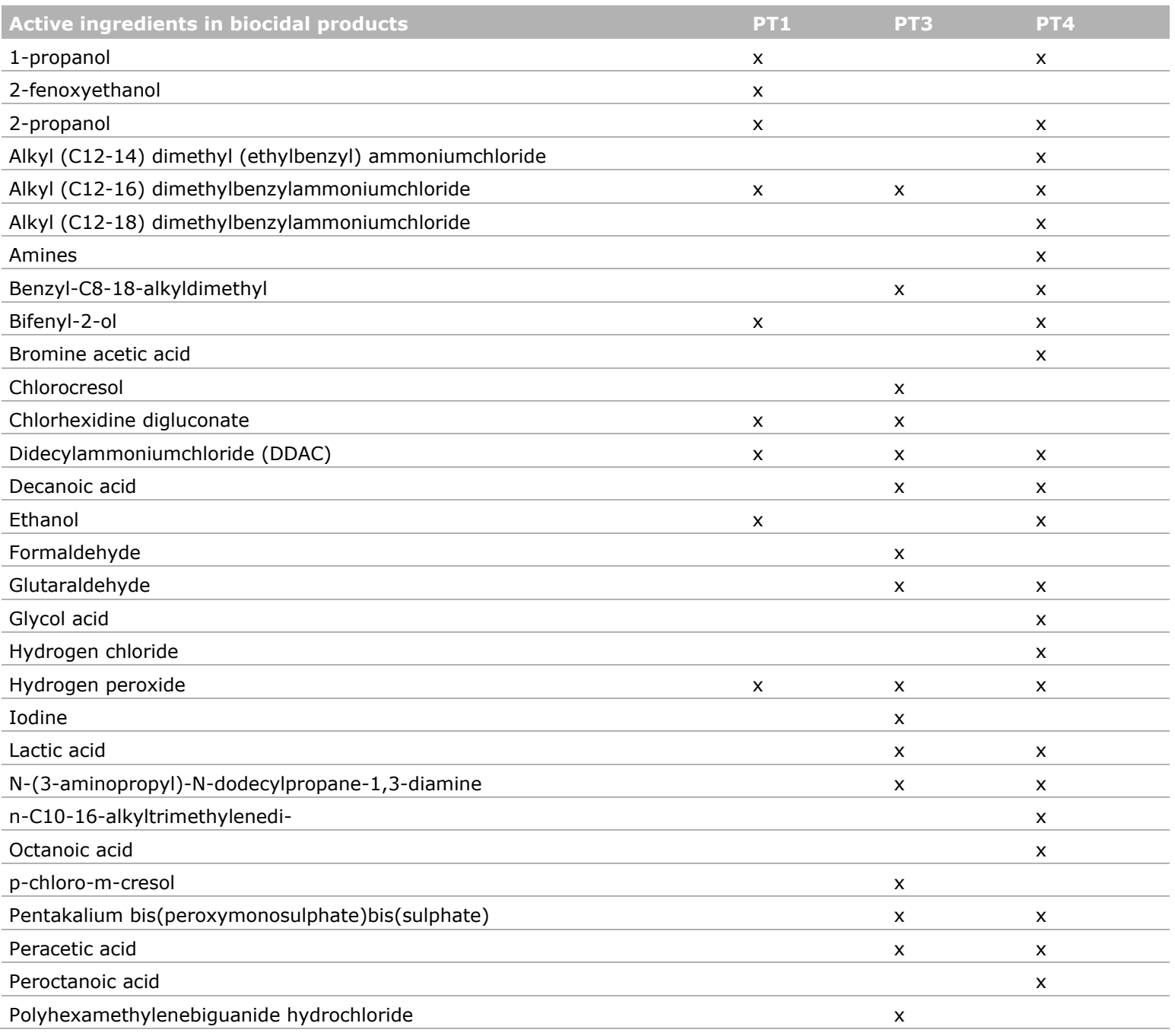




\begin{tabular}{lcc} 
Active ingredients in biocidal products & PT1 & PT3 \\
Reaction products with chloroacetic acid & $\mathrm{x}$ & $\mathrm{x}$ \\
\hline Salicylic acid & $\mathrm{x}$ \\
\hline Sodium benzoate & $\mathrm{x}$ \\
\hline Sodium bisulphate & $\mathrm{x}$ \\
\hline Sodium chlorite & $\mathrm{x}$ & $\mathrm{x}$ \\
\hline Sodium dichloroisocyanurate & $\mathrm{x}$ & $\mathrm{x}$ \\
\hline Sodium dichloroisocyanurate dihydrate & $\mathrm{x}$ \\
\hline Sodium hypochlorite & $\mathrm{x}$ \\
\hline Sodium percarbonate & $\mathrm{x}$ \\
\hline Sodium persulphate & $\mathrm{x}$ \\
\hline Sodium-p-toluene sulfonchloramide & $\mathrm{x}$ \\
\hline Tartaric acid & $\mathrm{x}$ \\
\hline Tetra-acetylethylenediamine & $\mathrm{x}$ \\
\hline
\end{tabular}

An overview of the most frequently used active ingredients in authorised biocidal products per PT is given in Figure 1 for PT1, Figure 2 for PT3 and Figure 3 for PT4. Important to note here is that active ingredients may be present in mixtures with other active ingredients and, thus, some biocidal products may contain more than one active ingredient. Furthermore, this overview only shows the active ingredients that are present in more than $5 \%$ of the authorised biocidal products.

Almost $90 \%$ of biocidal PT1 products is based on alcohols (such as ethanol and propanol) and in most of them these are the only active ingredients. Out of all the authorised biocidal products $(n=96)$, 13 consist of a mixture of alcohols and chlorine-based ingredients and two contain alcohol and hydrogen peroxide. Only a few biocidal products contain sodium benzoate and/or tartaric acid. Most of the chlorine-based products consist of sodium hypochlorite. Remarkably, all these products consist of only this active ingredient and are not in mixture with other active ingredients. The same accounts for sodium hypochlorite used in biocidal products authorised under PT3. Contrary to PT1, none of the biocidal products in PT3 contain alcohols.

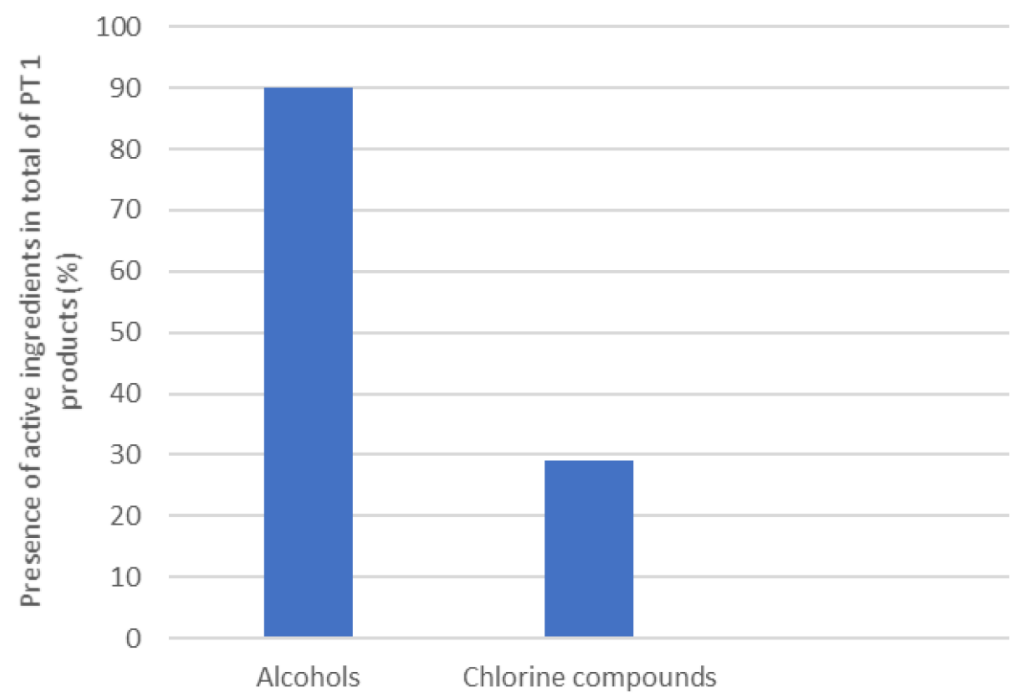

Figure 1 Presence of active ingredients in authorised biocidal products for product type 1 (PT1). Only active ingredients which are present in more than $5 \%$ of the authorised PT1 products were included.

Approximately $23 \%$ of the biocidal products in PT3 is chlorine-based. Active ingredients in these biocidal products are chlorocresol, sodium dichloroisocyanurate and sodium dichloroisocyanurate dihydrate. The latter active ingredient is often seen in biocidal products for the use of disinfecting animal stables and transport vehicles. While biocidal products with sodium dichloroisocyanurate are 
not authorised for the application in transport of animals, it may be applied in animal stables. In almost half of the chlorine-based biocidal products, sodium hypochlorite is used as single ingredient. These biocidal products may also be used for the disinfection of animal stables. The chlorine-based compound chlorohexidine gluconate is applied in biocidal products used for the disinfection of the teats of milk producing animals. Also iodine is used for the disinfecting teats of milk producing animals, but one product containing $2.8 \%$ iodine is used for disinfection of stables. Iodine is applied as single ingredient and is present in $15 \%$ of the biocidal products in PT3. A fifth of the biocidal products in PT3 contains hydrogen peroxide. The majority of these products is in combination with peracetic acid; some of them are combined with lactic acid and a few products contain only hydrogen peroxide. Another $20 \%$ of the biocidal products in PT3 contain quaternary ammonium compounds (quats), such as DDAC and alkyl (c12-16) dimethylbenzylammonium chloride. The two quats mentioned are often combined and sometimes in combination with an aldehyde. Around $15 \%$ of the biocidal products in PT3 contain aldehydes, like formaldehyde and glutaraldehyde. Only a few of these products contain aldehydes as a single ingredient.

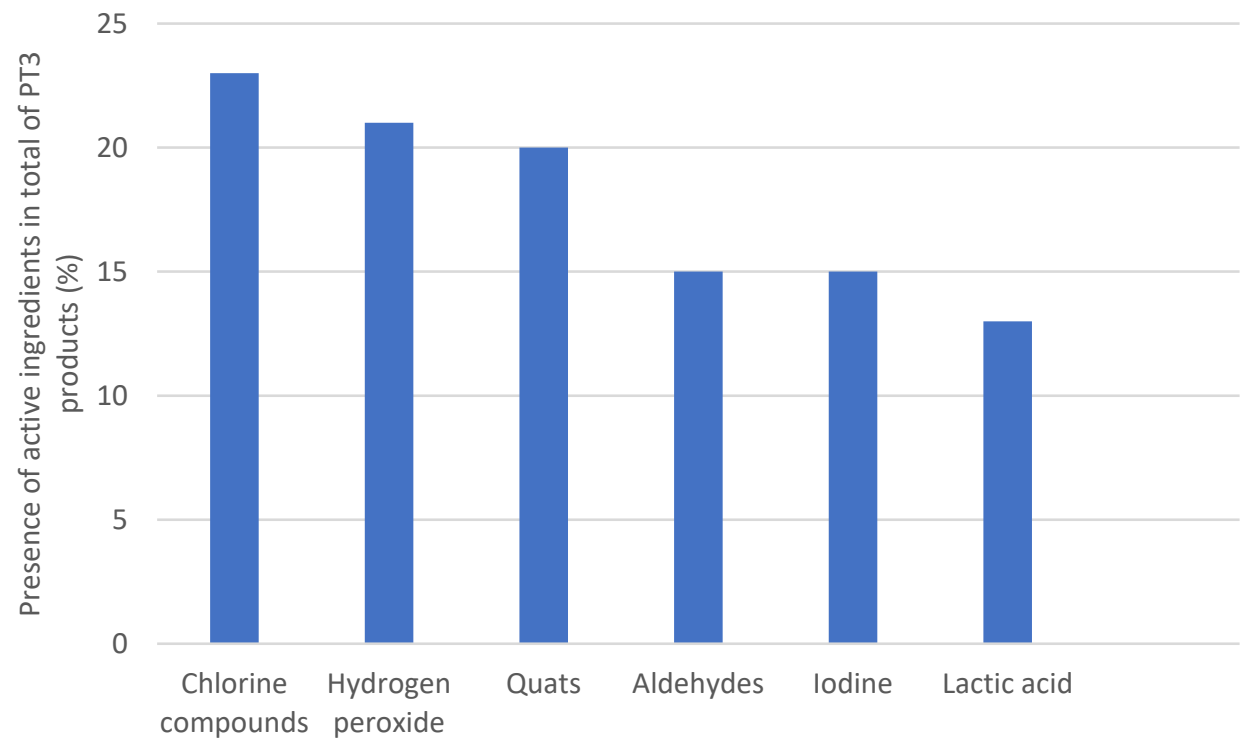

Figure 2 Presence of active ingredients in authorised biocidal products for product type 3 (PT3). Only active ingredients which are present in more than $5 \%$ of the authorised PT3 products were included.

More than a quarter of the biocidal products in PT4 contain quats. Out of these biocidal products, over $80 \%$ contain only DDAC. The other quat-based products contain alkyl (C12-16)

dimethylbenzylammoniumchloride or a combination thereof with glutaraldehyde and/or $\mathrm{N}$-(3aminopropyl) N-dodecyl. In some quat-based biocidal products in PT4, DDAC is combined with propane-1,3-diamine. Apart from quats, hydrogen peroxide is also frequently used in biocidal products within PT4. Hydrogen peroxide is often found in a mixture with peracetic acid or lactic acid amongst the authorised products. In approximately $32 \%$ of the products, hydrogen peroxide is present as single ingredient. These products are authorised for the application in food processing facilities for disinfecting surfaces. Almost a quarter of the biocidal products in this PT is chlorine-based, of which the majority contains sodium hypochlorite. Likewise as in PT3, sodium hypochlorite is the only active ingredient in these biocidal products. These products are authorised to be used for the disinfection of milking equipment and of surfaces in food processing facilities. The number of chlorine-based biocidal products with sodium hypochlorite is followed by the single use of sodium dichloroisocyanurate or sodium dichloroisocyanurate dihydrate. Only in some cases, it is used together with pentalkalium bis(peroxymonosulphate)bis(sulphate). Over $10 \%$ of the biocidal products in this PT are on the basis of alcohols. In most cases, this was on the basis of only ethanol, but some are combined with propanol. Only some biocidal products are a combination of ethanol and glutaraldehyde. As of April 2020, less than 10 biocidal products were on the basis of aldehydes. Formaldehyde, which is 
widely used in biocidal products in PT3, is not used at all in biocidal products in PT4. The active ingredient glutaraldehyde is used together with ethanol or quats. The active ingredients bifenyl-2-ol, bromine acetic acid, decane acid, hydrogen chloride, N-(3-aminopropyl)-N-dodecylpropane-1,3diamine, octane acid, pentalkalium bis(peroxymonosulphate)bis(sulphate), salicylic acid, sodium benzoate, sodium bisulphate, sodium chlorite and tartaric acid are each present in less than $5 \%$ of all biocidal products in PT4.

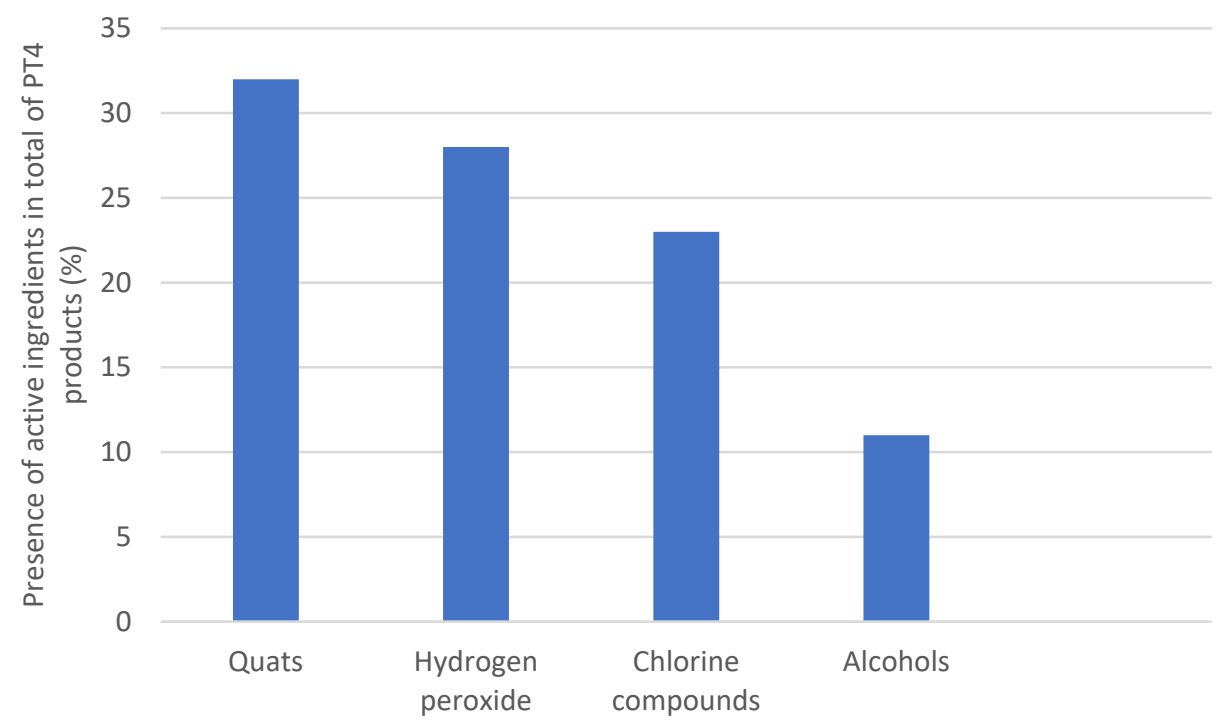

Figure 3 Presence of active ingredients in authorised biocidal products for product type 4 (PT4). Only active ingredients which are present in more than $5 \%$ of the authorised PT4 products were included.

Some active ingredients in the authorised biocidal products in PT1, PT3 and PT4 are also registered as food additives under Regulation (EC) No 1333/2008. Most of them are used in biocidal products in PT4 for the purpose of disinfecting equipment and surfaces in food processing facilities. These active ingredients, which are also registered as food additive, concern hydrochloric acid, lactic acid, sodium benzoate sodium bisulphate and tartaric acid and may be added to a specific foodstuff or food group in quantum satis. Quantum satis in this context means that there is not a numerical limit, but they can be used as much as is needed. However, from these active ingredients, only lactic acid (E270) may be applied to prepacked minced meat and meat preparation. With this, lactic acid is the sole active ingredient from these additives that may be used as food additive in the red meat chain (Ctgb 2020).

\subsubsection{Conclusion on authorised disinfection products}

The main authorised active ingredients in disinfectant products that can be used in the red meat and game meat chain include:

- Alcohol-based compounds (mainly ethanol and propanol) in PT1 and PT4

- Chlorine-based compounds (among others sodium hypochlorite) in PT1, PT3 and PT4

- Hydrogen peroxide (in combination with peracetic acid) in PT3 and PT4

- Quats (mainly DDAC and alkyl (C12-16) dimethylbenzylammonium chloride) in PT3 and PT4

- Aldehydes (glutaraldehyde, formaldehyde) in PT3

- Iodine in PT3

- Lactic acid in PT3

Authorisations of biocidal products are not restricted to the use in a specific animal sector. Therefore, a further specification of the use in the red meat or game meat chain cannot be made based on the Ctgb database. 


\subsection{Cleaning and disinfection products applied in red meat chain}

\subsubsection{Product uses according to publications found in the Google search}

The search in the Advanced Search feature in Google resulted in 660 hits in total for all 8 websites mentioned before. These hits were screened for relevance within the scope of this research based on the title. In the next step, 69 references were fully red. In case relevant information was found in the references, it was extracted and inserted into the literature overview, this was the case for 30 references. An additional search on Google resulted in three additional references that were added to the overview. The search in Scopus resulted in 10 hits, however, based on screening of the abstract they were considered irrelevant for this study as no specific information on cleaning and disinfection agents was described in these publications.

Limited active ingredients or the names of active ingredients were mentioned in the publications (Table 3). When mentioned, professional magazines reported experiences of new products. The use of longer existing biocidal products was not often reported in this literature. An example of a new upcoming biocidal product in literature is Nocolyse Food. This product contains the active ingredient hydrogen peroxide with a concentration of $7.9 \%$. This biocidal product is authorised since December 2015 for the application of disinfecting surfaces that may come in contact with food. The biocidal product is a gaseous product, which should fill the whole processing room. No rinsing is needed after the application of this biocidal product. However, it may only be applied by a person educated and certified for room disinfection and with the help of special equipment (Ctgb 2020). Another relatively new physical technique is the application of dry ice with the active ingredient carbon dioxide $\left(\mathrm{CO}_{2}\right)$. The carbon dioxide pellets are sprayed with pressure with the help of special equipment on the contaminated surface. In this way the carbon dioxide causes a thermo-shock that results in small ruptures in the layer of contamination, which makes the layer fall off (VMT 2019).

Besides the information on new disinfection techniques, professional magazines also reported challenges that the meat industry is facing. An overview of these challenges is described in section 3.4 .

Table 3 List of active ingredients used in the red meat chain based on literature

\begin{tabular}{llll} 
Active ingredients & $\begin{array}{l}\text { Parts of the } \\
\text { red meat chain }\end{array}$ & $\begin{array}{l}\text { Applied for hand hygiene, } \\
\text { walls/floor, materials }\end{array}$ & Literature source \\
Alcohol & Cold storage & Hand hygiene & (Grolleman.2020) \\
\hline Carbon dioxide (dry ice) & Processing & Machinery & 2019) \\
\hline Chlorohexidine digluconate & Not specified & Hand hygiene & (Vleesmagazine 2019) \\
\hline $\begin{array}{lll}\text { Didecyldimethylammonium chloride } \\
\text { (DDAC) }\end{array}$ & Not specified & Hand hygiene & (RIVM 2008) \\
\hline Ethanol (70\%) & Processing, catering & Equipment & (Voedingsindustrie 2015, \\
\hline industry & Processing & Room, machinery & Voedingsindustrie 2017, \\
& & & Voedingsindustrie 2018, \\
& & & Voedingsindustrie 2018, \\
& & & Voedingsindustrie 2019, \\
& & & Voedingsindustrie 2019) \\
\hline Lactic acid & & Small equipment & (GrollemanColdstores 2020) \\
\hline Lactic acid with hydrogen peroxide & Processing, retail & Equipment & (VMT 2020)
\end{tabular}




\subsubsection{RIVM biocides database}

In 2011, RIVM (National Institute of Public Health and the Environment) investigated the biocidal products that were publicly available in the Netherlands or were available online. These were both authorised and unauthorised products (RIVM 2012). Biocidal products that have been listed as unauthorised products by RIVM also include previously authorised products or products, which were only authorised in Belgium or the UK. However, the actual use of the products was not investigated. The active ingredients present in these PT3 and PT4 products are presented in Table 4 (detailed information was obtained via personal communication with RIVM). PT1 products were not included in this study.

Table 4 List of active ingredients available in 2011 for PT3 and PT4 based on the RIVM biocide database (RIVM 2012)

\begin{tabular}{|c|c|c|}
\hline Active ingredients in biocides on the market as found by RIVM* & PT3 & PT4 \\
\hline 1-proponal & & $x$ \\
\hline 2,2-dibromo-2-cyanoacetamide & $x$ & $x$ \\
\hline 2-propanol & $x$ & $x$ \\
\hline acetic acid & $x$ & \\
\hline alkyldimethylbenzylammonium chloride & $x$ & $x$ \\
\hline ascorbic acid & $\mathrm{x}$ & \\
\hline benzylalkyldimethylammonium chloride & $\mathrm{x}$ & $\mathrm{x}$ \\
\hline benzyl-C12-18-alkyldimethylammonium chloride & $x$ & $x$ \\
\hline chlorine dioxide & $x$ & $x$ \\
\hline chlorhexidine & $x$ & \\
\hline chlorxylenol & $x$ & \\
\hline chloramine (tosylchloramide sodium) & $x$ & \\
\hline chlorides & $x$ & $x$ \\
\hline chlorine & $x$ & $x$ \\
\hline chlorphene & $x$ & \\
\hline citric acid & $x$ & \\
\hline copper & $x$ & \\
\hline ethyl N-acetyl-N-butyl-(beta)-alaninate & $x$ & \\
\hline formaldehyde & $x$ & $x$ \\
\hline formic acid & $x$ & \\
\hline foromycene & $x$ & \\
\hline glutaraldehyde & $x$ & $x$ \\
\hline glyoxal & $x$ & \\
\hline hydrogen chloride & $x$ & $x$ \\
\hline hydrogen peroxide & $x$ & $x$ \\
\hline imazalil & $x$ & \\
\hline iodine & $x$ & \\
\hline lactic acid & $x$ & \\
\hline lauryldimethylbenzylammonium bromide & $x$ & \\
\hline magnesium-silicate & $x$ & \\
\hline m-cresol & $x$ & \\
\hline mytrimiomnium bromide & $x$ & \\
\hline $\mathrm{N}$-(3-aminopropyl)-N-dodecylpropane-1,3-diamine & $x$ & $x$ \\
\hline N,N-bis(4-chloorfenyl)-3,12-diimino-2,4,11,13-tetraazatetradecanediamidine & $x$ & \\
\hline
\end{tabular}




\begin{tabular}{|c|c|c|}
\hline Active ingredients in biocides on the market as found by RIVM* & PT3 & PT 4 \\
\hline paraformaldehyde & $x$ & \\
\hline p-chloro-m-cresol & $\mathrm{x}$ & $x$ \\
\hline peracetic acid & $\mathrm{x}$ & \\
\hline peroctanoic acid & $\mathrm{x}$ & \\
\hline polyvinylpyrrolidone iodine & $x$ & \\
\hline potassium hydroxide & $\mathrm{x}$ & \\
\hline quaternary ammonium compounds & $\mathrm{x}$ & $\mathrm{x}$ \\
\hline salicylic acid & $\mathrm{x}$ & \\
\hline sodium chlorite & $\mathrm{x}$ & \\
\hline sodium hypochlorite & $\mathrm{x}$ & $x$ \\
\hline sodium percarbonate & $x$ & $x$ \\
\hline sodium persulphate & $x$ & $x$ \\
\hline sodium dichlorisocyanurate & $x$ & $x$ \\
\hline sodium-p-toluenesulfonchloramide & $x$ & $x$ \\
\hline tetra-acetylethylenediamine & $x$ & \\
\hline zinc & $x$ & \\
\hline
\end{tabular}

*The active substances written in italics are the substances in marketed biocidal products as found by RIVM in 2011, but not in currently authorised biocidal products (April 2020) as described in the Ctgb database.

Besides some of the chemical ingredients mentioned in Table 4, also other ingredients were reported to be present in disinfection products, such as allontoine, aloe vera, citronella, dried plants (not specified), eucalyptus, lactose, lemon oil, marigolds, micro-organisms (not specified), minerals (not specified), oregano, pine oil, plant extracts (not specified), ricinus oil, seafoam, seaweed, talc and tea tree.

In total, 432 biocidal products belonging to PT3 and 771 biocidal products belonging to PT4 were found. The available biocidal products corresponding with PT4 were in $36 \%$ of the cases on the basis of quats. This was only for $5 \%$ of PT3 products. About $20 \%$ of the offered products belonging to PT4 contained hydrogen peroxide, mostly as single ingredient, followed by products where hydrogen peroxide was present in combination with peracetic acid. These products had the purpose of disinfecting machinery or surfaces in food processing facilities. Hydrogen peroxide was present in 46 out of the 432 products (11\%) in PT3; 40 of them were offered with the purpose, amongst others, of disinfecting milking equipment (non-agricultural buildings). In most cases, where peracetic acid was present, it was combined with hydrogen peroxide. Whereas peracetic acid was found in $12 \%$ of products corresponding to PT4, it was found in 6\% of PT3 products. Except for some products, sodium hypochlorite was used as single ingredient in biocidal products on the market. It was present in $14 \%$ and $20 \%$ for PT3 and PT4, respectively. In PT3, 16\% of the biocidal products was on the basis of aldehydes. This was only $5 \%$ for the biocidal products corresponding with PT4. In both PTs, these biocidal products consisted of multiple active ingredients in most cases. Biocidal products in PT3 were chlorine-based in $13 \%$ of the cases and only in 3\% for the PT4 products. Most of them described the application for disinfecting teats of milking animals (PT3) and for disinfecting machinery and surfaces in food processing facilities (PT4). The active ingredient lactic acid was only marketed to disinfect teats of milking animals and was present in $10 \%$ of products in PT3 and for disinfecting surfaces that can come into contact with food in a couple of products corresponding with PT4.

In PT4, 7\% of the available biocidal products contained alcohols. Most of these consisted of ethanol, followed by 2-propanol and a mixture of the two. In a lower amount, alcohols are combined with peracetic acid and/or hydrogen peroxide and/or glutaraldehyde. All the alcohol-based products in PT4 had the purpose of disinfecting surfaces, which may come in contact with food. For the alcohol-based products in PT3, the purpose could differ between disinfecting teats of dairy animals, animal transport or animal stables (RIVM 2012). 
In comparison to the currently authorised biocidal products in the Netherlands, the biocidal products on the market in the Netherlands in 2011, as found by RIVM, encompasses many more active ingredients. The 31 active ingredients that were found in biocidal products on the market in 2011 but are not present in currently authorised products are written in italics in Table 4. On the other hand, there are also nine active ingredients that are nowadays authorised to be used in biocidal products, which were not found in products on the market in 2011. These active ingredients are 2fenoxyethanol, bromoacetic acid, chlorocresol, glycol acid, n-C10-16-alkyltrimethyleendi-amine, octanoic acid, reaction products with chloroacetic acid, sodium benzoate, and tartaric acid.

\subsubsection{Conclusions on the use of cleaning and disinfection products based on literature}

Active ingredients used for cleaning and disinfection in de the red meat chain as mentioned in the recent literature were carbon dioxide, chlorohexidine digluconate, DDAC, ethanol (70\%), hydrogen peroxide and lactic acid. The literature was mainly focussed on new products or applications. In the RIVM research of 2011 a long list of used active ingredient in biocidal products was present. The majority of these active ingredients were also present in biocidal products authorised in April 2020. The most common active ingredients were also comparable. However, the list of active ingredients in biocidal products on the market in 2011 is longer than the list of approved active ingredients in biocidal products in April 2020. It was concluded by RIVM in 2011 that there are many biocidal products offered, which were not authorised anymore or were offered for the incorrect application. The actual use of these unauthorised ingredients in 2011 was unknown. 


\subsection{Hygiene protocols and procedures in de red meat chain}

The red meat chain is subject to hygiene protocols and the implementation of HACCP as described in Regulation (EU) 2017/625. Branch organisations can help the sector in setting up guidelines in the implementation of these protocols and procedures (COV 2018).

\subsubsection{Primary production}

During the literature study, no relevant information was obtained with regard to the cleaning and disinfection routines on farms.

\subsubsection{Transport}

Truck drivers should follow the protocols that are in force at the pick-up points of delivered animals for meat production. The driver should wear clothes and shoes provided by the company where the animals are loaded or unloaded. Disposable overalls may also be used. Clothes and shoes need to be put on before loading or unloading the animals and will be taken off when the loading or unloading is finished and the driver returns into the driver's cabin. At a slaughterhouse or at collecting points, the driver must bring his own overall and shoes for unloading the animals. Disposable clothing should be disposed of in bins destined for these at the premises and non-disposable clothing should be placed back into the truck. The same accounts for the shoes. However, these have to be cleaned and disinfected prior to storage. The driver has to make sure that the clothes and shoes he wears in the driver's cabin are not the same as those worn during loading or unloading the animals. Washing hands with water and soap has to occur before loading and after the driver has taken off the clothes after loading animals. Hands should be washed with water and soap before unloading, right after unloading and after undressing the clothes that were worn during unloading. After loading and upon departure of the truck, the wheels and wheel housing should be cleaned and disinfected. After unloading, the vehicle should be cleaned and disinfected at the premises at approved cleaning and disinfection sites (Reiniging- en Ontsmettingplaatsen (R\&O-plaatsen) (NVWA nd). Slaughterhouses and collecting areas for animals should have such an R\&O site. The NVWA has established a handbook for these R\&O sites to support the companies in this sector. An R\&O site that works according to the guidelines in this handbook is recognised as such by the NVWA (NVWA nd).

Cleaning of the truck must start from the inside towards the outside of the vehicle and from top to bottom. Removable particles on the vehicle should be taken apart and should be cleaned and disinfected separately. Cleaning comes before disinfection and cleaning consists of three steps. First, all dirt should be removed. Second, smaller dirt particles, such as fats, should be soaked. At this point, cleaning agents should be applied. Third, the soaked dirt together with the cleaning agent should be washed off with water. After cleaning, disinfection should take place according to the prescriptions of the disinfection agent. Although different clothing and shoes should be used in the driver's cabin than during loading and unloading, the driver's cabin should also be subject to a cleaning and disinfection routine. The vehicle and the driver should not come into the holding rooms of the animals. The driver has to drive directly to the place of destination after loading the animals. Some exceptions may occur on this point in the protocol. The first exception is when animals are loaded at a place where cleaning and disinfection was insufficient, or when the animals were loaded abroad, because procedures abroad may differ from those in the Netherlands. In this case, the driver should first go to the closest certified cleaning and disinfection point. Another exception is when the driver has to pick up animals from another premise. The animals from the first pick-up place should be loaded in a separate trailer, which should be parked on a public parking before entering the other loading premise. When the animals from the second premise are loaded in the vehicle, the trailer with the other animals can be picked up and be transported to the slaughterhouse for unloading. In general, cleaning and disinfection should always take place after something or someone has come in contact with the animals (Veelogistiek nd). 


\subsubsection{Slaughterhouse}

Before animals may enter the slaughter facility, they should be checked by an official inspector on the aspects of animal health, animal welfare and transportation. In principal, only healthy animals may be delivered. However, when an animal appears to be diseased, the official inspector should identify and separate the respective animal. When the animal is then reported fit for slaughter and the meat thereof would not pose a risk to human health, it will be slaughtered in a separate facility (Expertisecentrum Voedingsmiddelenindustrie 2019). After unloading the truck with the animals, the truck will be cleaned and disinfected at the appointed spot at the premises according to the protocol as described in section 3.3.2 (Veelogistiek nd).

During slaughter, the intestines are removed, which is a critical point in the slaughter process, since these organs are a reservoir of micro-organisms. After each action during slaughter, utensils are cleaned and disinfected (COV 2018). This is performed by first rinsing them with running water and putting them in water (COV 2018) that is constantly at a temperature of $82^{\circ} \mathrm{C}$ (Expertisecentrum Voedingsmiddelenindustrie 2019). The specially educated slaughterer constantly has 2 knives at his/her disposal so that a clean knife is always available. The slaughter halls and machinery therein are cleaned after each shift. These daily cleaning and disinfection routines are according to the hygiene code that each slaughter enterprise has described on the basis of HACCP (Hazard Analysis of Critical Control Points) (Expertisecentrum Voedingsmiddelenindustrie 2019). Each time operators enter the slaughter hall, a personal hygiene routine should be carried out. This includes new clean overalls, apron, boots, hair net, helmet and earplugs, and for operators working with knives a new clean chainmail glove for the hand opposed of the hand holding the knife (Vlees nd). When personal protection equipment is defective or damaged, it should be replaced (Anonymous 2020). Furthermore, hands should be washed and disinfected as well as the base of the boots (COV 2018). Hand washing is important for food safety of meat products, as well as for the health of the operators. In order to assure food safety of meat products, hand washing should take place each time before starting activities, when changing activities and when leaving the canteen. Besides, hand washing should take place each time after smoking, using the toilet, contact with head skin or wounds, picking something from the floor or sneezing, coughing or blowing the nose. For the sake of the operators' health, hand washing should take place each time before entering the canteen and before eating or drinking and after ending the activities or after taking of gloves (Anonymous 2020). Operators are not allowed to wear jewellery, piercings or make-up (Vlees nd). This accounts for any form of nail decoration, such as nail polish or false nails (Anonymous 2020). Experts in the field, as stated in literature, indicate that the highest compliance rate during personal hygiene routines can be achieved when the operators only have one way to enter the facility. This entrance should force the operators to conduct all steps in the personal hygiene routine before entering the slaughter hall. This is also known as a hygiene lock (Vakblad Voedingsindustrie 2017). In case an operator has infections, eczema, diarrhoea or another infectious disease, the supervisor should be informed. The supervisor should examine per case if the operator can continue working or should suspend the activities (Anonymous 2020). Despite the daily cleaning and disinfection and the personal hygiene routines, cross-contamination between carcasses can occur within one working shift. This can originate from the animals itself and may be spread due to flaws during the removal of the intestines. In order to prevent cross-contamination, microbiological samples are taken and analysed continuously during production. This also accounts for the water that is used to clean during the shift.

Slaughtering is subject to strict legislation and hygiene protocols. NVWA monitors compliance with respective legislation since 2015. Overall, 93\% of all monitored slaughterhouses in 2018 were compliant (Expertisecentrum Voedingsmiddelenindustrie 2019). Monitoring occurred on the aspects of delivery of animals, cleaning and disinfection of conveyance, skinning, removal of intestines, disinfection of utensils, contamination during slaughter, contamination of the finished product and the temperature during transportation of finished product. Among these aspects, cleaning and disinfection of conveyance could be improved the most. On average between 2015 and 2018, 83\% was compliant on this aspect (Expertisecentrum Voedingsmiddelenindustrie 2019, NVWA 2019). 


\subsubsection{Cold storage}

After the animals are slaughtered and the meat is cut, meat is stored cool $\left(<7^{\circ} \mathrm{C}\right)$. Before one may enter the packaging department or the plate freezing department, hands should be washed and treated with alcohol-based disinfectants. When needed for proper cleaning, machinery and/or equipment should be disassembled. Small objects, such as thermometers, door handles and control panels should be cleaned and disinfected with alcohol tissues. Door mats and working clothes are cleaned externally, by an external company (GrollemanColdstores 2020).

Most of the cleaning routines occurs at the end of each working day. The next morning, the department heads will check all the cleaning routines with the help of an inspection scheme. The cleaning routines should be marked with "satisfied" or "unsatisfied". In case of the latter, appropriate actions to solve the unsatisfactories should be taken and recorded. These actions should be taken before the production will start. Some objects are cleaned on a weekly basis. These concern the doors in the wet section of the packaging department and in the vacuum department, the walls in the cratewashing department and the plate freezing department and in the dry section of the packaging department, floors in the expedition, cooler and storage and the beams in conveyor belts. Also more general equipment and spaces that do not come in direct contact with the food products, such as dock shelters, pump trucks, forklifts and windows are cleaned once a week. The ceiling in the crate-washing department, the ceilings in general rooms, the condensers, and the outside terrain are cleaned on a monthly basis. The airbags are cleaned each quarter by an external company.

Once a month checks for residues of cleaning and disinfection agents are performed. In general, cleaning occurs before disinfection and rinsing afterwards with water and consequently drying by air. This is not the case when the disinfectant Kenosan lactic, consisting of active ingredient lactic acid, is used. This disinfectant is used without prior cleaning and without rinsing afterwards, which is in line with the prescribed usage of the biocidal product. Treated surface and equipment is just dried by air after disinfection with this biocidal product. Kenosan lactic is used for disinfecting small equipment in the packaging departments, expeditions, coolers, storage and plate freezer department (GrollemanColdstores 2020).

\subsubsection{Processing}

The cleaning and disinfection routine of the processing facilities can consist of five steps. First, rough contamination is removed by soaking and rinsing by water; this is called visual cleaning. Second, a foaming cleaning agent is applied in order to soak fats and proteins present on the surfaces. Third, this cleaning agent is washed off with water. Fourth, disinfection agents are applied to kill microorganisms. Fifth and final, the complete equipment and spaces, on which the disinfection agents are applied, are rinsed with water starting from top to bottom. This 5-step cleaning and disinfection routine is carried out after each working day. This means that it is mostly carried out at night. Once a week, the processing facility is treated with acid cleaning agents in order to remove limescale.

The hygiene protocol can affect the production planning, since meat with the highest risk will be produced last in order to prevent cross-contamination. For this purpose, beef is produced before pork, since it is deemed that pork can result in a higher level of microbiological contamination. Some enterprises chose to separate the production of poultry products from that of red meat products (Vakblad Voedingsindustrie 2017).

Dutch enterprises in the meat, fish and poultry industry $(n=132)$ were questioned on hygiene checks in a small survey by "Uw Business Online for Clean Machine". In this survey, questions were dedicated to the cleaning of crates for the transportation of meat. Over half of the respondents answered that there is no hygiene check after the cleaning of crates, in which the meat is stored and/or transported. Some enterprises (12\%) outsource such hygiene checks to external labs and almost a third of the respondents execute the hygiene checks after cleaning the crates internally (Vlees+ 2018). Labels on the sides of crates for the purpose of traceability of its content are seen as a drawback in the cleaning routine of the crates. The presence of labels on crates makes cleaning difficult and lowers the effectivity of the cleaning routine. A solution for this hick-up in the cleaning routine of crates is found 
in Inmould-barcode labels (IML). These barcodes are incorporated in the crate and consist of the same material (Vlees+ 2012).

\subsubsection{Suppliers of cleaning and disinfection agents}

Suppliers of cleaning and disinfection agents are not part of the red meat chain itself. However, these suppliers can inform and influence stakeholders of the red meat chain on cleaning and disinfection agents. Suppliers know the products and can help the stakeholders of the red meat chain by advising which products can be used for the needed purposes. Instructions on how to use the products are also provided by the suppliers and indicated on the product labels.

\subsubsection{Conclusions based on hygiene protocols}

Hygiene protocols are often offered by branch organisations or the NVWA in order to guide the stakeholders in the branch to implement good practices. However, there is a paucity of information on hygiene protocols in the first stage of the red meat chain, the primary production. Stakeholders work according to the protocols and the type of cleaning and disinfection agents are laid down in protocols and/or HACCP plans. How these cleaning and disinfection agents should be applied is described in specification sheets and on the label of the agents. Suppliers of cleaning and disinfection agents are not part of the red meat chain; however, they can advise the stakeholders in the red meat chain on the agents used.

Overall, the cleaning and disinfection procedure occurs in 5 steps;

1. Removing and/or soaking rough dirt

2. Applying the cleaning agent to soak fats and proteins on surfaces

3. Rinsing with water to wash away the cleaning agent and soaked dirt

4. Applying the disinfection agent

5. Rinsing with water to remove the disinfection agent 


\subsection{Challenges related to cleaning and disinfection in the red meat chain}

This paragraph describes different challenges encountered in the publications found in the advanced Google search regarding cleaning and disinfection in the red meat chain.

The first challenge is the development of resistance against biocidal products. For this reason it is important to vary between biocide types in order to refrain effectiveness of disinfection (Vleesmagazine 2019). Another reason for ineffectiveness of disinfection can be the protection of the target organism by another micro-organism. A research on Salmonella showed that the effectivity of disinfection is 3 times lower on Salmonella that is present in the protozoa Tetrahymena. Salmonella free in solution or packed in the protozoa Tetrahymena was exposed to calcium hypochlorite. Important to note, this active ingredient is not present in the biocidal products as authorised by Ctgb. When calcium hypochlorite was applied to the solution at $2 \mathrm{ppm}$, the survival rate of Salmonella was 4.6-fold higher in the protozoa than that of the free Salmonella. However, when calcium hypochlorite was applied with a concentration of $3 \mathrm{ppm}$, none of the Salmonella survived, whether in the protozoa or free (Brandl, Rosenthal et al. 2005). The Salmonella bacteria are not digested by the parasite and will be excreted in the pork again, in case the parasite is present (Vleesmagazine 2012).

Another problem in the cleaning procedure in the red meat chain may be that machinery can only be properly cleaned during the process. Examples of such machinery are conveyor belts and riflings. Nevertheless, cleaning and disinfection agents shouldn't come in direct contact with food (Vleesmagazine 2018) and thus cleaning during production is hampered. Solutions for this are presented by means of steam, which is applied on conveyor belts while running (Vleesmagazine 2019).

In some cases, a cleaning routine may seem effective, but can rather be a source of crosscontamination. Machinery for processing meat may be designed with several covers in order to protect the meat product from aerial contamination. However, these covers can form a hotspot for meat residues, where micro-organisms can accumulate. Therefore, a hygienic design of such machinery does not consist of unnecessary covers as well as other wholes, crevices and unevenness (Vleesmagazine 2015). Another false security is cleaning drains with a high-pressure hose. When Listeria monocytogenes is present in a meat processing facility, it is often found in the drains (Vleesmagazine 2013). When the drains are then treated with high-pressure, the water can splash upwards and spread the bacteria into the room. This was shown in a study where Listeria monocytogenes was detected on surfaces at a height of $160 \mathrm{~cm}, 48$ hours after cleaning drains with high-pressure hoses (Vleesmagazine 2012).

In conclusion, the challenges encountered in this paragraph are mainly related to microbiological food safety issues. They are related to the development of resistance of microorganisms against biocidal products, difficulties with cleaning and disinfection of complex machinery and cross contamination of microorganisms due to cleaning or disinfection procedures. 


\subsection{Results of interviews and questionnaires for the red meat chain}

In total, 136 invitations were sent by email to fill in the questionnaire or for an interview. Questionnaires and invitations for interviews were sent to companies or organizations involved in the different parts of the red meat chain. Questionnaires were also sent to companies specialized in cleaning or disinfection at farms, to suppliers of cleaning and disinfection products and to the NVWA.

The response rate of the 136 invitations was $28 \%$ (i.e. 38 replied). Of the 38 replies, $42 \%$ (i.e. 16 replies) could not be used. This was because either it was irrelevant for the company to respond or indicated that they did not want to respond (37.5\%), they were not part of the red meat chain (25\%), or they had no time due to the coronavirus pandemic or non-specified reasons (25\%). Also, some respondents referred to other experts, who were then contacted (12.5\%). Overall, there was a $16 \%$ relevant response rate (i.e. 22 replies), of which 17 participants filled in the questionnaire and 5 were interviewed (on general aspects of cleaning and disinfection, primary production, transport, slaughterhouse, and cold storage).

Table 5 Response rate for questionnaires and interviews per part of the red meat chain

\begin{tabular}{|c|c|c|c|c|c|}
\hline $\begin{array}{l}\text { Parts of the red meat } \\
\text { chain }\end{array}$ & Additional information & $\begin{array}{l}\text { Invitations } \\
\text { sent }\end{array}$ & $\begin{array}{l}\text { Irrelevant } \\
\text { responses }\end{array}$ & $\begin{array}{l}\text { Relevant } \\
\text { responses }\end{array}$ & $\begin{array}{l}\text { Reported responses } \\
\text { per part of the chain* }\end{array}$ \\
\hline Primary production & $\begin{array}{l}\text { Mainly via branch } \\
\text { organisations }\end{array}$ & 8 & 3 & 1 & \multirow[t]{2}{*}{3} \\
\hline $\begin{array}{l}\text { Cleaning and disinfection } \\
\text { companies for primary } \\
\text { production }\end{array}$ & & 11 & 2 & 2 & \\
\hline Slaughterhouse & 15 small/middle, 15 large & 29 & 3 & 6 & 4 \\
\hline Cutting plant & & 14 & 1 & 0 & 5 \\
\hline Cold storage & & 14 & 2 & 1 & 4 \\
\hline Processing & $\begin{array}{l}14 \text { meat products, } 15 \\
\text { minced /mechanically } \\
\text { separated }\end{array}$ & 29 & 1 & 4 & 7 \\
\hline General & & 2 & 0 & 1 & $\begin{array}{l}1 \text { (general response) + } \\
11 \text { additional responses } \\
\text { from inspectors }\end{array}$ \\
\hline Total & & 136 & 16 & 22 & $33(+11)$ \\
\hline
\end{tabular}

*Some respondents were situated throughout the red meat chain, with some taking up multiple activities in the different parts of the chain.

From the twenty-two useable responses, respondents were situated throughout the red meat chain, with some taking up multiple activities, e.g. at the slaughterhouse, cutting plant, cold storage, or processing. Therefore, the total number of respondents per part of the chain is higher than the actual number of relevant responses (i.e. 33 instead of 22). In the following sections, the results of the questionnaires and interviews are provided per part of the chain, along with the number of relevant responses: primary production (3), transport (4), slaughterhouse (4), cutting plant (5), cold storage (4), and processing (7). Results from suppliers of cleaning and disinfection agents (5), and the NVWA, as the supervising body (1), are also described. In addition to these questionnaires and interviews, supplemented responses from NVWA inspectors (11) are provided in this section. An overview of the response rate for questionnaires and interviews per part of the red meat chain can be found in Table 5 .

\subsubsection{Active ingredients used for cleaning and disinfection}

The active ingredients that are used for cleaning and disinfection in the red meat chain, as indicated in the questionnaires and interviews, are outlined per part of the chain in Table 6 The specific applications are also indicated in this table. Some active ingredients, like DDAC, sodium hypochlorite, 
and alcohol-based ingredients, like ethanol, were reported to be used frequently by respondents (nine different instances cited). This is followed by hydrogen peroxide $\left(\mathrm{H}_{2} \mathrm{O}_{2}\right)$ with eight instances, other chlorine-based products with five instances, and peracetic acid with five instances. BAC, potassium hydroxide, sodium hydroxide, and hand soap were also mentioned in four separate instances. During some interviews it was indicated that only water was used for cleaning, without addition of active ingredients, this was indicated in two interviews regarding cleaning in the primary phase and this was also indicated by one respondent in the cold storage phase for cleaning of the crates. During the questionnaires and interviews there was not always a distinction made between cleaning and disinfection agents. Some ingredients can also be used for both cleaning and disinfection. In Table 6 is indicated which substances are approved biocides by Ctgb, which substances are mainly used as cleaning agents (based on ECHA database) and for some substances is indicated that this is a group of substances.

Table 6 Active ingredients and their application during cleaning and disinfection per part of the red meat chain, based on questionnaires and interviews.

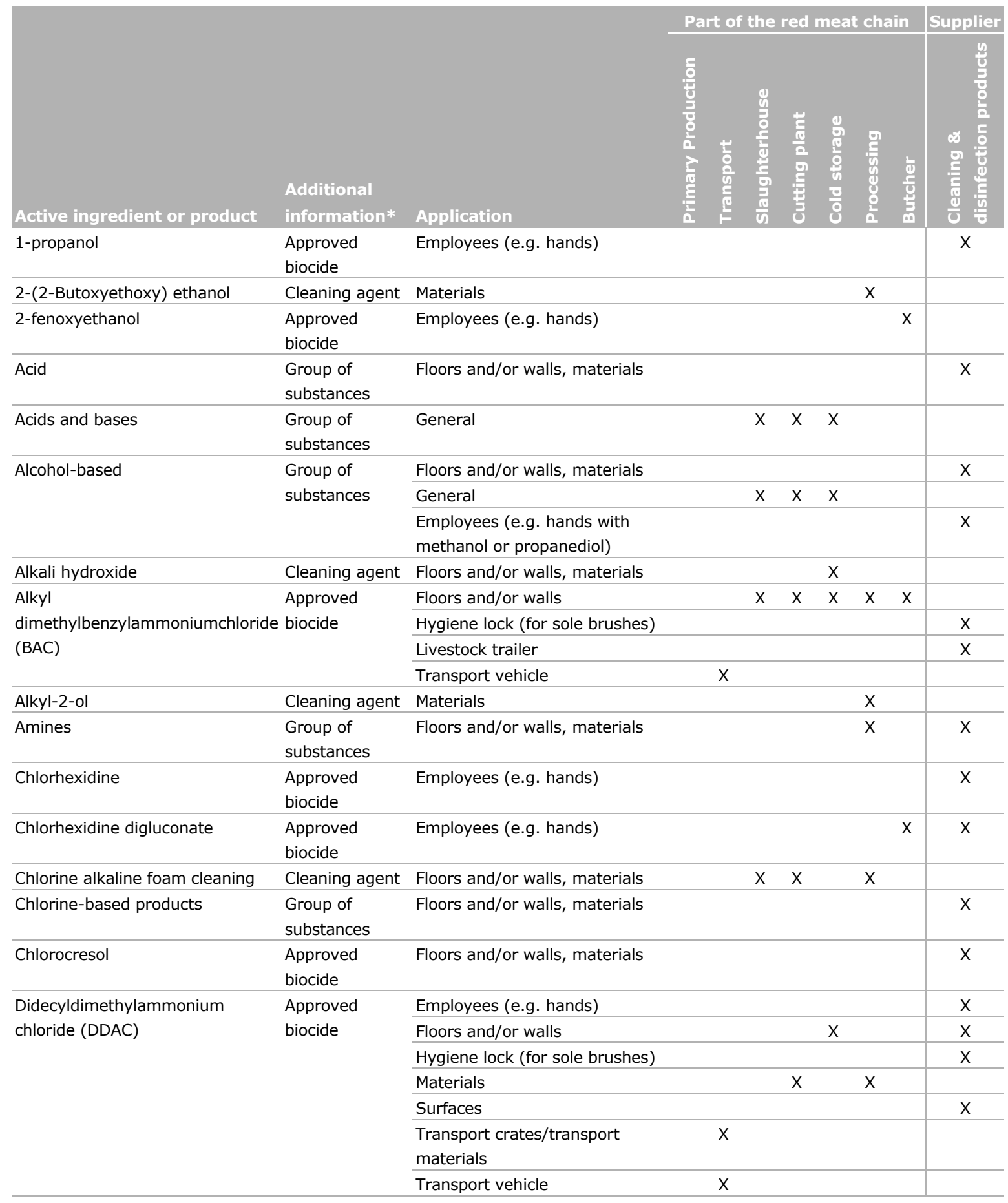




\begin{tabular}{|c|c|c|c|c|c|c|c|c|c|c|}
\hline \multirow[b]{2}{*}{ Active ingredient or product } & \multirow[b]{2}{*}{$\begin{array}{l}\text { Additional } \\
\text { information* }\end{array}$} & \multirow[b]{2}{*}{ Application } & \multicolumn{7}{|c|}{ Part of the red meat chain } & \multirow[b]{2}{*}{ 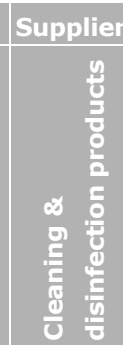 } \\
\hline & & & 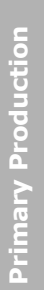 & $\begin{array}{l}\frac{}{\circ} \\
\frac{8}{0} \\
\frac{0}{2} \\
\frac{2}{2}\end{array}$ & 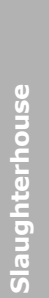 & 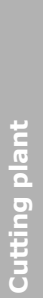 & 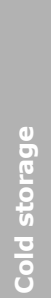 & $\begin{array}{l}\frac{0}{5} \\
\frac{5}{4} \\
\frac{8}{8} \\
\frac{0}{2}\end{array}$ & 홍 & \\
\hline Dodecylmethylamide oxide & Cleaning agent & Floors and/or walls & & & & $\mathrm{x}$ & $x$ & $x$ & & \\
\hline \multirow[t]{2}{*}{ Ethanol } & \multirow{2}{*}{$\begin{array}{l}\text { Approved } \\
\text { biocide }\end{array}$} & Employees (e.g. hands) & & & & $\mathrm{x}$ & & $x$ & $x$ & $x$ \\
\hline & & Floors and/or walls, materials & & & & & & & & $x$ \\
\hline Alcohol ethoxylates & Cleaning agent & Materials & & & & & & $x$ & & \\
\hline $\begin{array}{l}\text { Ethylenediaminetetraacetic acid } \\
\text { (EDTA) }\end{array}$ & Cleaning agent & Floors and/or walls, materials & & & & & & $x$ & & $x$ \\
\hline $\begin{array}{l}\text { Enzymatic cleaning product (e.g. } \\
\text { Prime biomix P) }\end{array}$ & Cleaning agent & Materials & & & $x$ & $x$ & $x$ & $x$ & $x$ & \\
\hline Formaldehyde & $\begin{array}{l}\text { Approved } \\
\text { biocide }\end{array}$ & Transport vehicle & & $x$ & & & & & & \\
\hline \multirow[t]{2}{*}{ Glutaraldehyde } & \multirow{2}{*}{$\begin{array}{l}\text { Approved } \\
\text { biocide }\end{array}$} & Floors and/or walls, materials & & & & & & & & $x$ \\
\hline & & Transport vehicle & & $x$ & & & & & & \\
\hline Hand soap & Cleaning agent & Employees (e.g. hands) & $x$ & $x$ & $x$ & $x$ & $x$ & $x$ & $x$ & $x$ \\
\hline \multirow[t]{4}{*}{ Hydrogen peroxide } & \multirow{4}{*}{$\begin{array}{l}\text { Approved } \\
\text { biocide }\end{array}$} & Floors and/or walls, materials & & & & & & $x$ & & $x$ \\
\hline & & Materials & & & & & & $x$ & & \\
\hline & & Surfaces & & & & & & & & $x$ \\
\hline & & Transport vehicle & & $x$ & & & & & & \\
\hline Isopropyl alcohol (2-propanol) & $\begin{array}{l}\text { Approved } \\
\text { biocide }\end{array}$ & Employees (e.g. hands) & & & & & & & & $x$ \\
\hline Isotridecanol & Cleaning agent & Materials & & & & & & $x$ & & \\
\hline Lactic acid & $\begin{array}{l}\text { Approved } \\
\text { biocide }\end{array}$ & Floors and/or walls, materials & & & $x$ & $x$ & $x$ & $x$ & & $x$ \\
\hline Lye & Cleaning agent & Floors and/or walls, materials & & & & & & & & $x$ \\
\hline $\begin{array}{l}\mathrm{N} \text {-(3-aminopropyl)- } \mathrm{N} \text { - } \\
\text { dodecylpropaan-1,3-diamine }\end{array}$ & $\begin{array}{l}\text { Approved } \\
\text { biocide }\end{array}$ & Hygiene lock (for sole brushes) & & & & & & & & $x$ \\
\hline Nitric acid & Cleaning agent & Floors and/or walls, materials & & & & & $x$ & & & \\
\hline $\mathrm{N}$-oxides & Cleaning agent & Floors and/or walls, materials & & & & & & $x$ & & \\
\hline $\begin{array}{l}\text { Pentakalium bis(peroxymono- } \\
\text { sulfaat)bis(sulfaat) }\end{array}$ & $\begin{array}{l}\text { Approved } \\
\text { biocide }\end{array}$ & $\begin{array}{l}\text { Stables, materials in stables, } \\
\text { transport crates/transport } \\
\text { materials, employees }\end{array}$ & $x$ & & & & & & & \\
\hline \multirow[t]{3}{*}{ Peracetic acid } & \multirow{3}{*}{$\begin{array}{l}\text { Approved } \\
\text { biocide }\end{array}$} & Floors and/or walls, materials & & & $x$ & $x$ & & $x$ & & $x$ \\
\hline & & Surfaces & & & & & & & & $x$ \\
\hline & & Transport vehicle & & $x$ & & & & & & \\
\hline \multirow[t]{2}{*}{ Phosphoric acid } & \multirow[t]{2}{*}{ Cleaning agent } & Floors and/or walls & & & & & $x$ & & & $x$ \\
\hline & & Materials & & & & & $x$ & & & \\
\hline Potassium hydroxide & Cleaning agent & Floors and/or walls & & & $x$ & $x$ & $\mathrm{x}$ & $x$ & $x$ & \\
\hline & & Materials & & & & & & $x$ & & $\mathrm{x}$ \\
\hline Propan-2-glycol & Cleaning agent & Materials & & & & & & $x$ & & \\
\hline $\begin{array}{l}\text { Quaternary ammonium } \\
\text { compounds }\end{array}$ & $\begin{array}{l}\text { Group of } \\
\text { substances }\end{array}$ & Floors and/or walls, materials & & & & & & & & $x$ \\
\hline Sodium alkylbenzene sulfonate & Cleaning agent & Materials & & & & & & $x$ & & \\
\hline Sodium chloride & $\begin{array}{l}\text { Approved } \\
\text { biocide }\end{array}$ & $\begin{array}{l}\text { Stables, materials in stables, } \\
\text { transport crates/transport } \\
\text { materials, employees }\end{array}$ & $x$ & & & & & & & \\
\hline Sodium cumenesulfonate & Cleaning agent & Materials & & & & & & $x$ & & \\
\hline $\begin{array}{l}\text { Sodium dichlorisocyanurate } \\
\text { (dihydrate) }\end{array}$ & $\begin{array}{l}\text { Approved } \\
\text { biocide }\end{array}$ & Transport vehicle & & $x$ & & & & & & \\
\hline Sodium hydroxide & Cleaning agent & Floors and/or walls & & & & $x$ & $x$ & $x$ & & $x$ \\
\hline & & Materials & & & & & & $x$ & & $x$ \\
\hline Sodium hypochlorite & Approved & Crate washer & & & & & & & & $x$ \\
\hline & biocide & Floors and/or walls, materials & & & $x$ & $x$ & $x$ & $x$ & $x$ & $x$ \\
\hline Sodium lauryl ether sulfate & Cleaning agent & Materials & & & & & & $x$ & & \\
\hline $\begin{array}{l}\text { Sodium-p- } \\
\text { toluenesulfonchloramide }\end{array}$ & $\begin{array}{l}\text { Approved } \\
\text { biocide }\end{array}$ & Transport vehicle & & $x$ & & & & & & \\
\hline Trisodium phosphate & Cleaning agent & Materials & & & & & & $x$ & & \\
\hline
\end{tabular}

* Additional information indicates which substances are approved biocides by Ctgb, which substances are mainly used as cleaning agents (based on ECHA database) and for some substances is indicated that this is a group of substances 


\subsubsection{Cleaning and disinfection in practice}

\subsubsection{Primary production}

At the farm, respondents $(n=3)$ indicated that the main reasons for cleaning and disinfection were to prevent the introduction and potential spread of pathogens and to provide clean pens for the animals. The farmers indicated that they have a routine for cleaning and disinfection and are aware of the best practices in case disinfectants should be used.

When asked how often cleaning or disinfection products are used, one respondent indicated that they do so when the barn is empty and after transport. In contrast, another respondent indicated they only clean (i.e. they do not disinfect) since disinfection is out of the scope for their company. A third respondent did not answer this question.

Respondents were also asked which active ingredients for cleaning and disinfection could potentially endanger public health if residues were to get into the product (e.g. from the production of byproducts). Two of the three respondents did not respond, while one said "none" since they indicated that it works based on an "oxidizing system."

Respondents were also asked how the correct use of cleaning and disinfection agents is guaranteed. This question had eight sub-questions, which are outlined below for clarity (Table 7).

Table 7 Eight sub-questions related to the correct use of cleaning and disinfection agents

\begin{tabular}{ll} 
No. & Sub-question \\
i. & if cleaning is always performed before disinfection \\
\hline ii. & if there is always a rinse after cleaning and disinfection \\
\hline iii. & how the minimum exposure time is ensured \\
\hline iv. & how the correct concentration is applied \\
\hline v. & how is it prevented that unauthorised substances are used \\
\hline vi. & where they get information about cleaning and disinfection and if additional information was required
\end{tabular}

One respondent did not answer these sub-questions. However, the respondent noted an exceptional situation where agents were then used after an expert was called for assistance. From that exceptional situation, the farm does not have any agents other than what had remained. Otherwise, the use of cleaning and disinfection agents is limited. Another respondent answered 'yes' to (i) and not applicable to (ii). There were no responses provided for the remaining sub-questions. Finally, a third respondent, who was part of the primary production and transport stages, did not respond to sub-questions (i) and (ii) but had done so for the remaining sub-questions. The (iii) minimum exposure time is ensured since the operation is immediate, and the contact time is always reached. The use of correct concentrations (iv) and correct agents ( $v$ ) is explained by the supplier of agents and will be followed. The concentration mentioned is $1 \%$ (noted as $1 \mathrm{~kg}$ per $100 \mathrm{~L}$ water). For (vi), biocide legislation applies here, and the label should be followed. This respondent indicated that for (vii) and (viii), they use a bio swab test kit, where one can take a hygiene sample and determine the total viable count (TVC) of micro-organisms (www.biosecurity.nl/bio-swab).

\subsubsection{Transport}

For transport, respondents $(n=4)$ indicated that the main reasons for cleaning and disinfection were focused on food safety, including hygiene and preventing cross-contamination, as well as preventing the transmission of animal diseases. For the latter, after unloading livestock, the trailer must always be cleaned and disinfected on site. From the responses, this step is not always possible or is performed insufficiently because resources and facilities are limited or unavailable. Thus, hygiene during transport for the red meat chain is a challenge. 
When asked how often cleaning or disinfection products are used, the responses varied. One respondent indicated that it was performed daily, while another indicated that it was done after every transport. Another respondent specified that it was performed after every trip after the animals were unloaded. This frequency could vary from $1 x$ per week to $4 x$ per day. Finally, another respondent indicated that they disinfect the transport vehicle at least $4 x$ per year and aim to do so once per month (12x per year). This respondent noted that they transport $99 \%$ packaged food, so the probability of cross-contamination is minimal.

When respondents were asked which active ingredients for cleaning and disinfection could potentially endanger public health if residues were to get into the product, the responses were mixed. One respondent did not respond, while another indicated they were unsure, but that specialists about disinfectants (Ctgb) should be consulted. Another respondent indicated that the question was not applicable, as they did not produce, but only stored and transported packaged products. A fourth respondent, the same mentioned earlier for primary production, replied "none" since they indicated that it works based on an "oxidizing system."

Respondents were also asked how the correct use of cleaning and disinfection agents is guaranteed. One respondent was part of transport and primary production stages; their results have already been outlined in the primary production section. Another respondent provided a general response to this question, indicating that it is not done. Instead, at most, there are random sampling checks performed by the NVWA or by the Human Environment and Transport Inspectorate (in Dutch, the Inspectie Leefomgeving en Transport (ILT)). In short, the entrepreneur must ensure proper application. This respondent plus two other respondents further responded to most of the sub-questions (see Table 7). Cleaning is always performed before disinfection, and there is always a rinse after cleaning and disinfection.

Respondents had various answers regarding (iii) how the minimum exposure time is ensured, such as by doing so according to the instructions, watching the clock, or arranging it with the driver.

Regarding (iv) on the application of the correct concentration, this is set up automatically with the equipment. However, one respondent noted that this procedure is also arranged with the supplier of the disinfection products. For $(v)$, on ensuring that the correct agents are used for their corresponding application, these three respondents, once again, had varying answers. These included relying on the vessel connected to the system, reading the label, or by checking ones-self by arranging checks with the NVWA or with ILT and registering that information. It should be ensured that the use of unauthorised substances is prevented ( $\mathrm{vi}$ ), which can be achieved by not allowing the substance to be on-site or purchased (e.g., by implementing a purchasing policy restriction). This procedure can also be checked during internal and external audits or via other random (annual) checks.

Regarding (vii), on the procedures to control cleaning or disinfection, one respondent provided no reply. Another respondent elaborated that they deal with packaged materials and do no transport an open product, so additional checks are not needed. The third respondent indicated that the supervising body must perform these procedures at approved cleaning \& disinfection sites (R\&O-plaatsen). Also, the driver does this at other approved cleaning and disinfection sites (R\&O-plaatsen). Moreover, random checks can be carried out by the government or performed with quality systems.

Finally, respondents indicated that they received their information about cleaning and disinfection (viii) from a variety of resources. These included the British Retail Consortium (BRC) Standard for Storage and Distribution (S\&D standard), the International Organization for Standardization (ISO) 22000, which concerns food safety management, via newsletters, and their supplier. Drivers also obtained this information from government regulations, quality systems, sector protocols, and courses. Respondents did not indicate that they needed additional information.

\subsubsection{Slaughterhouse}

At the slaughterhouse, respondents $(n=4)$ indicated several reasons for cleaning and disinfection. Preventing (cross-)contamination of micro-organisms and keeping microbiological values of meat products low were noted. Furthermore, they indicated that having a clean and safe working environment each day is essential. Cleaning of the materials and lines is also necessary to prevent 
cross-contamination of allergens. Moreover, removing animal remains is needed to prevent crosscontamination from other species.

A need for self-control is evident to ensure food safety of the products. Control of Listeria in meat products is required. Risks associated with cleaning and disinfection are described in companies' Hazard Analysis and Critical Control Point (HACCP) plans. One respondent noted that the use of handbooks (e.g. a prepared handbook on African Swine fever) and workshops (e.g. on Listeria) have helped to disseminate knowledge on cleaning and disinfection. However, this respondent stipulated that additional guidelines are needed on which cleaning and disinfection products can be used and when they can be used. Also, one slaughterhouse respondent noted that each truck is checked by the veterinarian (or another inspector) of the NVWA. This check includes if animals are healthy, if the truck is clean (so far), etc. Further, they check if the cleaning and disinfection are performed correctly and that the agents are used correctly. For example, samples are taken from the high-pressure washing hoses to check that the correct solution is used.

When asked how often cleaning or disinfection products are used, the respondents varied in their details. Two respondents indicated daily, with one indicating that cleaning and disinfection of both the environment and equipment are performed. Moreover, this respondent - which is also part of the cutting plant and processing stages - noted that to counteract resistance, they perform alkaline cleaning $4 x$ per week and acid cleaning $1 x$ per week. For disinfection, that is performed $1 x$ with lactic acid and $4 x$ with another agent. This schedule is performed according to the advice of an external firm. A third respondent - which is also part of the cutting plant, processing, and cold storage indicated that cleaning and disinfection of the slaughterhouse were performed once a week after slaughter (on Thursday). The processing location and machines are cleaned daily with a steam cleaner and an enzymatic cleaning product (Prime biomix P. product ${ }^{3}$ ). Then, once per week (on Saturday), they clean the processing location and cold storage with an alkaline-based chlorinated foam cleaning and disinfectant product (Foodclean SR 5, active ingredients include: alkali and sodium hypochlorite) in combination with the steam cleaner and detergent (Prime biomix P). Finally, a fourth respondent indicated that personal hygiene is continuous. Also, materials like gloves and aprons are cleaned at each break. The premises are also cleaned and disinfected after the working day or between shifts.

When respondents were asked which active ingredients for cleaning and disinfection could potentially endanger public health if residues were to get into the product, there was a range of answers. One of the four respondents did not respond to this topic. Another respondent indicated that they served customers who do not allow the use of quaternary ammonium compounds in production but did not further provide a response to this topic. A third respondent was unaware of a potential human health concern. It was indicated that they rinse everything to ensure that no residues get into the product. Finally, a fourth respondent noted the potential for resistance. They also indicated that chlorine agents could be left behind. However, there is always a rinse after cleaning and disinfection, so the likelihood was limited.

Respondents were also asked how the correct use of cleaning and disinfection agents is guaranteed. All reported that cleaning is always performed before disinfection. Three of the four respondents indicated that (ii) there is always a rinse after cleaning and disinfection. The fourth respondent indicated that this was not performed after disinfection, which was in accordance with the disinfectant instructions.

Respondents had various answers regarding (iii) how the minimum exposure time is ensured. These were based on the instructions provided by a cleaning company, the time - which is observed by an external firm based on a clock in the production area, globally with a further explanation that they are just aware of the time, as well as based on specification sheets and their HACCP plan. Regarding (iv) on the correct application of the concentration, they pre-calculate this based on the dose stated on the product packaging, or they make use of calibrated sprayers or periodic checks of all dosing units by titration. One respondent did not respond to this sub-question. For ( $v$ ), on ensuring that the correct agents are used for their corresponding application, responses were similar. They make use of work

\footnotetext{
3 For further information, see: https://www.primeslab.nl/reinigen-winkel.html
} 
instructions and visual checks by, for instance, the foreman of the cleaning company. One respondent specified that due to the small-scale of their slaughterhouse, all employees know which resources should be used for which purpose. Another respondent did not respond to this sub-question. It should be ensured that ( $\mathrm{vi}$ ) the use of unauthorised substances is prevented, which can be achieved by having a purchasing procedure and entry control so that only authorised substances are supplied. Also, cleaning plans reflect this regarding the frequency and type of products allowed. Two of the respondents specified the NVWA, one indicating that the NVWA supervises it, and the other indicating that they have cleaning and disinfection agents recommended by the NVWA and are suitable for the purpose they are to be used.

Regarding (vii), on the procedures to control cleaning or disinfection, the responses were varied. One respondent noted that given their small-scale, they do not do this, instead they 'only stop cleaning when everything is clean.' Another respondent specified that for smaller companies, they could have their own codes or use hygiene codes, while large slaughterhouses operate from HACCP. Another respondent indicated that they have procedures, such as checking the $\mathrm{pH}$ or performing microbiological analyses (type unspecified) before production. A fourth respondent specified that they perform daily visual checks before production and for any deviating values found for the contact surfaces; these are reviewed and controlled again. Afterwards, production can start. Further, the respondent noted that they verify weekly disinfection effectiveness by using agar plates to check for the presence of micro-organisms.

Finally, respondents indicated that they received their information about cleaning and disinfection (viii) from a variety of resources. They get information from (chemical) suppliers, cleaning companies, colleagues, and business contacts in other sectors. One respondent indicated that they also attended conferences and read professional publications. Another respondent did not mention these routes; instead, they indicated that this information is checked during the NVWA audit, and they have received suitable information from them. This respondent specified that no further information was needed at the time. Two of the respondents did not address that sub-question. However, one respondent was curious about water suitability and innovation with the reduction of water use after using (foam) cleaning products.

\subsubsection{Cutting plant}

At the cutting plant, respondents $(n=5)$ provided the same reasons for cleaning and disinfection as at the slaughterhouse. This similarity was because all but one respondents were from both a combined slaughterhouse and cutting plant. That one respondent indicated that food safety was the main reason for cleaning and disinfection and that cleaning or disinfection products were used daily. When asked to indicate which active ingredients for cleaning and disinfection could potentially endanger public health if residues were to get into the product, that one respondent answered that there is always a rinse with clean water. He did not further specify any active ingredients.

Respondents were also asked how the correct use of cleaning and disinfection agents is guaranteed. The one respondent that was not already mentioned in the section on slaughterhouses, responded to all sub-questions (Table 7). For this cutting plant, cleaning is always performed before disinfection. Also, there is always a rinse after cleaning and disinfection. To ensure that the minimum exposure time is reached (iii), they follow a cleaning protocol. This protocol is used, along with the instructions on the packaging, to ensure that the correct concentration is applied (iv). Also, the cleaning protocol and label on the packaging are consulted to ensure that the correct agents are used for their corresponding application $(v)$. The respondent indicated that to prevent the use of unauthorised substances ( $\mathrm{vi}$ ), they purchase from certified companies (the type of certification or examples thereof were not specified). For (vii) on the procedures used to control cleaning and disinfection, they consult a checklist and perform microbiological research. Finally, when asked (viii) where they get their information about cleaning and disinfection, and if more information was required, they indicated that the microbiological results are leading. They did not specify if additional information was required.

\subsubsection{Cold storage}

During cold storage, respondents $(n=4)$ indicated that the main reasons for cleaning and disinfection were focused on food safety, hygiene, and control. Cleaning and disinfection are performed to have a 
clean and safe working environment, prevent (cross-)contamination of micro-organisms, kill bacteria, and deliver a clean and attractive end-product. One respondent indicated that by having these measures for cleaning and disinfection in place, the company can progress, which is yet another goal.

When asked how often cleaning or disinfection products are used, two respondents indicated daily. Another respondent, as mentioned above for slaughterhouses, cleaned the cold storage once per week (on Saturday). Finally, one cold storage respondent further specified the cleaning and disinfection routine. This routine is performed once per day. This occurs at night when production is stopped since then a complete cleaning routine can be carried out. At the same time, there is another production line where the different products are packed, where cleaning/rinsing with only water is performed when the type of product is changed to avoid residues of the agents in the food product.

When respondents were asked which active ingredients for cleaning and disinfection could potentially endanger public health if residues were to get into the product, the responses were limited. Two of the four respondents did not provide an answer to this question. Another respondent (indicated during slaughterhouse as well) was not aware of this because rinsing was performed until all residues were removed.

Respondents were also asked how the correct use of cleaning and disinfection agents are guaranteed. All reported that cleaning is always performed before disinfection. Two of the four respondents indicated that (ii) there is always a rinse after cleaning and disinfection. The remaining two respondents were the same as those indicated earlier in the section slaughterhouse, both of which followed the instructions or the procedure when rinsing is not required.

Respondents had various answers regarding (iii) how the minimum exposure time is ensured. These were based on the instructions provided by a cleaning company, globally - with a further explanation that they are just aware of the time taken. One respondent further specified that applying foam in all the company departments takes an hour; after this, the departments are rinsed in the same order. Therefore, the foam stays at least for an hour. Regarding (iv) on the correct application of the concentration, they pre-calculate based on the dose stated on the product packaging, they make use of calibrated sprayers, or the procedure is automated. For instance, one respondent specified that the process is automated in the pipeline. The company possesses four pipelines, which employees can use immediately. One pipeline is with plain water, one with air, and the other two with appropriate cleaning/disinfectant solutions. These pipes are measured several times a year for acidity $(\mathrm{pH})$. This respondent later indicated that manual application is also performed. Only a few designated persons are allowed to use the agents, and they have been trained to do so. For ( $v)$, on ensuring that the correct agents are used for their corresponding application, responses varied. Respondents make use of work instructions and visual checks or read the label. One respondent specified that due to the small-scale of their facilities, all employees know which resources should be used for which purpose. Another respondent noted that it is based on the expertise of their employees. An expert (from an external company) trains these employees. Also, some agents are used that can be applied throughout the facility. This helps to reduce the possible misuse (application) of an agent.

Finally, a respondent indicated that there are no problems with reading the instructions for use (for cleaning and disinfection products). Also, the agents are not used by all employees, as only a few employees are specially designated for cleaning tasks (the company employs its own cleaners), who can apply the agents.

In order to ensure that ( $\mathrm{vi}$ ) the use of unauthorised substances is prevented, having a purchasing procedure and entry control so that only authorized substances are supplied was noted. One respondent indicated that they have cleaning and disinfection agents recommended by the NVWA and are suitable for the purpose they are to be used for. Another respondent specified that the quality controller is responsible for this, he/she checks and archives everything present on-site (at least $2 x$ per year). There is a list of all available agents on-site. It is updated as soon as a new agent is added. Also, Material Safety Data Sheets (MSDS) of all these agents are archived. 
Regarding (vii), on the procedures to control cleaning or disinfection, the responses varied, even despite that one of the four respondents did not provide an answer. One respondent indicated that they have procedures, such as checking the $\mathrm{pH}$ or performing microbiological analyses (type unspecified) before production. Another respondent noted that given their small-scale, they do not this, instead they 'only stop cleaning when everything is clean.' Another respondent specified that for smaller companies, they could have their own codes or use hygiene codes, while large slaughterhouses operate from HACCP. A third respondent further specified the frequency of the procedures. The expedition chief checks (every night) the cleaning routine against a checklist. Once per week, the check on the cleaning routine is performed by a quality person and a cleaning expert. Once per month, the cleaning routine is checked by an outside external company. Also, once per month, an external party checks for residues of quaternary ammonium compounds (quats), cleaning agents, and proteins. Once per month, Listeria is checked on-site (internal check), while an external party checks the presence of Salmonella.

Finally, respondents indicated that they received their information about cleaning and disinfection (viii) from a variety of resources. They get information from suppliers, cleaning companies, and colleagues. One respondent indicated that the expertise is available in-house. Another respondent did not mention these routes; instead, they indicated that this information is checked during the NVWA audit, and they receive suitable information from them. Two respondents indicated that additional information was not required. Also, two of the respondents did not address this sub-question.

\subsubsection{Processing}

Processing takes place in the tertiary phase of the red meat chain, which consists of trade, processing, and consumption. Butchers are also part of the tertiary phase of processing. During processing, respondents $(n=7)$ indicated that the main reasons for cleaning and disinfection were food safety, hygiene, and working according to HACCP. Preventing (cross)-contamination of microorganisms, killing bacteria, and removing dirt, possible allergens, or animal remains were indicated. Finally, being able to deliver quality or an attractive product as well as working in a clean and safe environment was specified.

When asked how often cleaning or disinfection products are used, three respondents indicated daily. Another respondent further specified that for employees and materials, this was several times a day, while for the floors and walls, this was every day, sometimes even several times per day. One respondent indicated that for employees, this was upon entering production, during production, after leaving the production, and after visiting the toilet. For materials, this was during the break, after a change of product type, and at the end of the day. Finally, for the environment, this was performed daily after production. The remaining two respondents had both slaughterhouse and cutting plant activities; these respondents are previously outlined in the section on slaughterhouse, specifying the cleaning and disinfection programs.

When respondents were asked which active ingredients for cleaning and disinfection could potentially endanger public health if residues were to get into the product, responses varied. Three of the seven respondents did not respond, while one indicated 'all.' Another respondent indicated 'chemicals' and 'alcohols.' The remaining two respondents had both slaughterhouse and cutting plant activities. These respondents are previously outlined in the section on slaughterhouses where they (i) serve customers who do not allow quats in production and (ii) are unaware since they rinse away all residues.

Respondents were also asked how the correct use of cleaning and disinfection agents is guaranteed. All, but one, reported that cleaning is always performed before disinfection. That one respondent did not provide an answer to sub-questions (i) and (ii). The remaining five respondents all indicated that there was always a rinse after cleaning and disinfection (ii), with one of them noting an exception if the MSDS indicates otherwise.

Respondents had various answers regarding (iii) how the minimum exposure time is ensured. These were based on working according to a cleaning plan or protocol, the instructions provided by a cleaning company, the time - which is observed by an external firm based on a clock in the production area, globally with a further explanation that they are just aware of the time, as well as having trained 
staff and short working time (of the agent). Regarding (iv), on the correct application of the concentration, responses varied. They pre-calculated this based on the dose stated on the product packaging, calibrate the equipment, perform periodic checks of the dosing units, use an automatic dosing unit, and follow-up with the product information sheet for personnel. Also, one respondent noted that they purchase fixed adjustment from suppliers and have machines set to the correct concentration once. For ( $v$ ), on ensuring that the correct agents are used for their corresponding application, responses were similar. They make use of work instructions, intensive training, and visual (daily) checks, by, for instance, the foreman of the cleaning company. They also consult the advice of cleaning companies and have fixed cleaners that perform the cleaning. One respondent noted that given the 'small-scale' of their company, the routines are fixed. All employees are aware of the resources to be used and the purpose of use. It should be ensured that (vi) the use of unauthorised substances is prevented, which can be ensured by purchasing products (e.g. only those permitted in the food industry) in consultation with the quality assurance department or having a defined cleaning plan or dedicated cleaners. One respondent emphasized that they use cleaning and disinfection products recommended by the NVWA and, given their small-size, everyone is aware of which products are suitable for which purposes and how to use them.

For (v), on ensuring that the correct agents are used for their corresponding application, responses were slightly different. One respondent makes use of product sheets and instructions. The other respondent noted that all employees are aware of the resources to be used and the purpose of use.

Regarding (vii), on the procedures to control cleaning or disinfection, the responses varied. One respondent noted that given their small-scale, they do not do this, instead they 'only stop cleaning when everything is clean.' Two other respondents responded positively, indicating that they use work instructions for the set-up or perform analyses like ATP measurement, $\mathrm{pH}$ checks, agar checks, and Listeria checks. A fourth respondent indicated that they operate according to HACCP. Finally, a fifth respondent provided a detailed response, specifying that they perform daily visual checks before production and for any deviating values found for the contact surfaces; these are reviewed and controlled again. Afterwards, production can start. Further, the respondent noted that they verify weekly disinfection effectiveness by using agar plates to check for the presence of microorganisms. Another respondent indicated "yes" and that these are discussed with the external cleaning company and its own staff. Before production starts, the staff checks whether thorough cleaning has been carried out (how this was performed was not further specified).

Finally, respondents indicated that they received their information about cleaning and disinfection (viii) from a variety of resources. They get their information from a knowledge base (unspecified), legislation, hygiene codes, cleaning companies, and (chemical) suppliers. One respondent indicated that they also attend conferences and read professional publications. Another respondent did not mention these routes; instead, they indicated that this information is checked during the NVWA audit, and they receive suitable information from them. This respondent specified that no further information was needed at the time. Finally, one respondent indicated that there was no need for this, according to information from the $\mathrm{KTBA}^{4}$.

\subsubsection{Suppliers of cleaning and disinfection agents}

Suppliers $(n=5)$ indicated various reasons for the importance of cleaning and disinfection. Maintaining the microbiological quality of products, preventing contamination (e.g., of the meat), and daily maintenance of installations (equipment) to ensure durability and correct operation were specified. When it came to the equipment, suppliers noted that assuring its proper working condition between productions was important for food safety and health. Also, suppliers mentioned the need to lower the number of pathogens, animal health, safe production with minimal antibiotic use, and preventing re-contamination to the extent possible. Food safety and health for humans, including consumers, were also highlighted.

When asked how often cleaning or disinfection products are used, four of the five suppliers responded. One indicated at every vacancy, while another indicated after production and interim at, e.g., the

\footnotetext{
4 Respondent presumed to be referencing this company: https://www.ktba.com/
} 
cutting plant. A third respondent indicated that this was performed at least daily and specified that this reply was in the context of the food industry (from slaughterhouse until catering). A fourth respondent specified that, in principle, objects are cleaned and disinfected once a day. Crates are often done so after every use. Personal hygiene is performed before and after work, and at any interruption for a toilet visit or break.

When respondents were asked which active ingredients for cleaning and disinfection could potentially endanger public health if residues were to get into the product, the responses varied. One of the five respondents did not answer the question. Another respondent indicated that they do not have experience here, but that they perceived it to be "small" since, after use, there must always be a rinse. Also, such products are only used in an empty stable or a specific department. A third respondent indicated "all ingredients," and indicated that it is legally obliged to rinse until neutral pH. Only products without a no-rinse stated are "without risk" with alcohol as an example. A fourth respondent indicated that their MSDS should be consulted. Finally, a fifth respondent provided a detailed answer. They first pointed to chlorates, followed by a similar trend for quats in the context of resistance. However, they did indicate that when used correctly (e.g. concerning dosage), there is no impact on the development of resistance. Further, this supplier motivates that they spend much time on training and monitoring of customers when it comes to the correct use of cleaning agents and biocides. Besides efficacy, the toxicological and ecotoxicological impacts are gaining more attention.

Respondents were also asked how the correct use of cleaning and disinfection agents is guaranteed. One of the five respondents did not answer this question, nor the sub-questions (Table 7). None of the suppliers was asked sub-question viii since they are the experts themselves. Three of the respondents indicated 'yes' for (i), one of which noted it was standard advice, and another indicated an exception for livestock trucks, where only water is sprayed before disinfection. The remaining respondent indicated that it was dependent on whether a product was registered as a cleaning and disinfection product (dirty conditions) or only as a disinfectant (clean conditions). They further elaborated that it is nowhere stipulated that 'cleaning' is with detergent, so if one can remove all visual/organic/mineral contamination by simply rinsing, that this is sufficient for 'cleaning.' They have observed that most of the 'abuse' is related to ready-to-use sprays based on isopropyl alcohol or ethanol (so-called alcohol disinfection). These products are always only registered as a disinfectant. They are often used in combination because of their degreasing effect, quick-drying time, or no need for water (i.e. because of their easy use). This respondent further elaborated with an example about where the control of carcass temperature is with a probe thermometer, that is seldom cleaned and is always 'just' disinfected with an alcohol wipe.

The four respondents had various answers regarding (ii) if there is always a rinse after cleaning and disinfection. Two indicated yes, with one noting an exception 'unless there is a no-rinse approval.' $\mathrm{A}$ second respondent indicated that this must be done officially but questioned whether it always happens in practice. The fourth respondent answered that, in general, the product must be rinsed, but that more products that do not require a rinse are coming onto the market. These products are mainly based on a mixture of isopropyl alcohol, hydrogen peroxide, or lactic acid. If the certificate of admission does not state that there is a need to rinse, no rinsing should be done (the document states what should be done, not what should not be done). Most problems at the level of rinsing are not so much in the non-rinsing but insufficient thorough rinsing. However, International Featured Standard (IFS) / BRC quality manuals already require validations there. On the other hand, attention must also be paid to allow certain products to dry up (longer contact time than necessary), because of which certain residues dry up and become more difficult to rinse. Quats are an excellent example of this. Other active substances pose comparatively less risk at this level because they react away (peracetic acid, hydrogen peroxide, alcohols).

Respondents varied regarding (iii) how the minimum exposure time is ensured. One respondent indicated that it was not guaranteed in practice; after soaping, there is often a break so that the exposure time is achieved. Another respondent noted the work sequence (those that are first injected are cleaned first), and to schedule the breaks correctly. A third respondent indicated that surface hygiene usually uses foaming products, and the foam shows where it has or has not been applied. 
Also, the foam helps to achieve the correct contact time. A fourth respondent indicated the need for training, cleaning instruction sheets, follow-up, and validation to ensure this.

Regarding (iv), on the correct application of the concentration, responses varied. One respondent had indicated that this was achieved with dosing systems, and foam/cleaning-in-place (CIP) systems with adjustments. However, another respondent indicated that the correct equipment was important (e.g. with the dosage fixed on the high-pressure sprayer). A foam gun is seen as inaccurate, and the dosage can easily be adjusted; thus, it is not advised. A third respondent noted that for surface hygiene, the equipment is important; where detergents and disinfectants are drawn in, the correct concentration is achieved through medium orifices in the suction or a control valve. For hygiene of crates, this is achieved by conductivity or proportional dosing. Finally, the fourth respondent indicated that periodic calibration by the supplier was important. Also, they noted there are many tools for customer control (based on $\mathrm{pH}$ titration, rapid tests/strips, conductivity, etc.).

For (v), on ensuring that the correct agents are used for their corresponding application, responses varied. One respondent indicated that the expertise of the supplier of the resources, advice, a cleaning plan, and validation by a company with the Quality, Health, Safety, and Environment (QSHE, in Dutch: Kwaliteit, Arbo en Milieu (KAM)) is needed. Another respondent indicated to work according to protocols with the product names listed. Also recommended was to work with different colour products in combination with materials to avoid mistakes. A third respondent indicated that businesses should use hygiene procedures, and if staff are well trained and working accurately, that should be fine. However, they do indicate that it is a weakness in the system. Finally, the fourth respondent indicated to record the proposed use on the label, to use technical datasheets, and with further support of product selection by the supplier.

In order to ensure that ( $\mathrm{vi}$ ) the use of unauthorised substances is prevented, suppliers noted that using correct information (through $\mathrm{Ctgb}$ ) and taking care of their customers, for example with training and follow-up, is important. One of the respondents indicated that using unauthorised substances cannot be prevented.

Finally, regarding (vii), on the procedures to control cleaning or disinfection, the responses were similar. One respondent indicated 'yes' and that hygiene monitoring systems are available (see hygienepartner.nl). Another respondent noted that this could be done with a visual inspection, ATP measurement, and microbiological checks. A third respondent, once again, noted measurements to evaluate the quality of cleaning with an ATP test, although this test is not suitable for measuring the effectiveness of the disinfection. Instead, disinfection can be measured with other plating methods such as RODAC 5 plates. Finally, the fourth respondent indicates several possibilities that are also available for the customer to carry out. First, to check with a visual inspection, possibly supplemented with an ATP test. For microbiology, one can use dip slides, RODAC plates, swabs, but there are also all kinds of specific rapid tests. Regarding residues, many simple measuring techniques can already provide an initial indication.

\subsubsection{Supervising body (NVWA)}

The NVWA indicated that cleaning and disinfection practices are only checked when there is reason to do so. During the inspections, other aspects, besides cleaning and disinfection, receive more attention.

The NVWA indicated that in general there are a few reasons for the cleaning and disinfection in the red meat chain. Controlling biofilms and Listeria were specified. In the primary production phase, pathogens like Campylobacter and Hepatitis virus are common and cannot be prevented.

Consequently, there is more attention and resources, including supervision, in the later parts of the chain, especially during slaughter.

In addition to the interview performed with the NVWA, there were eleven completed questionnaires received from the NVWA inspectors. These inspectors were coming from several parts of the red meat

\footnotetext{
5 RODAC $=$ Replicate Organism Detection And Counting. Can be used for microbiological control of surfaces.
} 
chain, including processing and butcher (phase III) as well as from the restaurant industry or foodservice outlets (in Dutch: Horeca).

When asked which active ingredients are used for cleaning by employees (e.g. hands), floor and/or walls of the facilities, and materials in/at the facilities, the responses varied. Sometimes it was unknown to the inspectors. Some others indicated that for employees, soap or alcohol-based gels or soaps (e.g., Sterillium $($ ) ) were used for hand cleaning. For the floor, walls, and materials at the facilities, alcohol-based products, chlorine-based compounds or products (e.g. Suma Tab), and halamid $^{6}$ (active ingredient: sodium P-toluenesulfonamide) are used. Of the eleven respondents, two were more elaborate. Both were inspectors for 'horeca' and butchers. One indicated that for the floors and walls, chlorine bleach and preparations based on quats, (lactic) acid, alcohols, or UV-light are used. The other inspector indicated that professional resources are used by 'better' horeca; otherwise, everyday household cleaning products are used.

Regarding the frequency of cleaning, the responses varied. Some indicated that it should be daily or multiple times per day to a few times per week. Other inspectors were less certain, as it could be very diverse, and it is often difficult to judge. One inspector indicated that they are posing this question less often.

When inspectors were asked which active ingredients for cleaning and disinfection could potentially endanger public health if residues were to get into the product, the responses varied. Of the eleven, some had no idea (2) or did not respond to the question (2). The remaining inspectors indicated that products that are chlorine-based, alcohol-based (ethanol), those that contain quats or other aggressive substances are of concern. One inspector noted that all cleaning and disinfection agents they had listed (including those that are chlorine-based, halamid, or general cleaners) could be of concern.

In response to the sub-questions related to cleaning and disinfection practices (Table 8), some inspectors answered that this is not the focus of the inspections. The inspectors did not always answer all the sub-questions. Below is a summary of the most relevant responses. Inspectors indicated that labels and instructions from suppliers of cleaning and disinfection agents should be followed. However, one inspector indicated that due to time limitations, these instructions are rarely read. This inspector mentioned that, in general, the knowledge about cleaning and disinfection is limited even in large companies, mainly when one's own personnel performs the cleaning and disinfection. This is because cleaning for a food company is different from cleaning at home. This inspector's experience was that upon further questioning, the knowledge of the in-house staff is often too limited regarding the dose to be applied and the method of application. Rinsing could be skipped when the processing time is overnight, and the personnel arriving in the morning could easily skip this step. Since cleaning procedures are rarely tested due to a lack of priority or time, control is mainly limited to assessing the end result. Furthermore, it was indicated - by the same inspector - that small companies use household disinfection products.

\subsubsection{Conclusions based on interviews and questionnaires}

The main conclusions for the questionnaires and interviews are as follows:

- A detailed overview of active ingredients and their application during cleaning and disinfection per part of the red meat chain is presented in Table 6. Alcohol-based products, chlorine-based products, DDAC, hydrogen peroxide, sodium hypochlorite, and peracetic acid were frequently reported ingredients used for disinfection. Hand soap, potassium hydroxide, and sodium hydroxide were frequently used throughout the chain for cleaning.

- During primary production (phase I), the use of cleaning agents and disinfection agents was limited. The cleaning or disinfection can be performed by an external company.

- During transport, cleaning and disinfection are not consistently performed due to insufficient resources or limited or unavailable facilities. The frequency of cleaning during the transport phase also depends on the type of transport vehicle. There are different cleaning regimes needed if the vehicle is used for transporting of live animals (more frequent) or packaged foods (less frequent).

\footnotetext{
6 See Ctgb: https://toelatingen.ctgb.nl/nl/authorisations/619
} 
- Smaller slaughterhouses or companies could have less detailed hygiene codes or may have less knowledge about cleaning and disinfection. Also, smaller slaughterhouses sometimes indicated less frequent cleaning and disinfection schedules. NVWA inspectors indicated that smaller companies might make use of 'normal' household products. Larger companies could afford analytical checks of disinfection performance and in-house specialists on cleaning and disinfection.

- In general, cleaning and disinfection (during phase II and phase III), according to those in the chain, are performed by trained, designated, internal or external personnel. However, according to one NVWA inspector, knowledge about cleaning and disinfection at both small and large companies is limited.

- Overall, those in the chain indicated that instructions for cleaning and disinfection agents are followed, and, when indicated in the instructions, rinsing occurs after cleaning and disinfection. However, NVWA inspectors indicated that given time limitations, instructions for the use and application of agents are rarely read by users, which could result in improper use of products.

- Possible concerns for human health from the use of cleaning and disinfection agents were unknown, or many respondents have limited knowledge. Alcohols, quats, and the by-products of chlorine-based products, like chlorate, were indicated by some respondents to be of possible human health concern. However, it was also indicated that because rinsing is performed, all residues should be removed.

- Those involved at the slaughterhouse, cutting plant, or cold storage (phase II), as well as processing (phase III), usually invested in keeping their knowledge and expertise up-to-date. Information provided by and audits performed by the NVWA helped to keep knowledge and practices up-to-date. In comparison, NVWA inspectors indicated that cleaning and disinfection have no priority during inspections, only when there is a specific reason to focus on this from a chemical or a microbiological point of view.

- Education and training should continue in all parts of the chain. Guidelines on which cleaning and disinfection products can be used and when they can be used are still needed, especially for primary production, transport, and for smaller companies.

- Overall, the focus is more on microbiological food safety than on chemical food safety in terms of analyses performed and knowledge obtained. 


\subsection{Decontamination in the red meat chain}

Chemical decontamination of carcasses can be performed during slaughter. Common substances used for chemical decontamination of meat are organic acids, such as lactic acid, acetic acid, citric acid, and fumaric acid. Other chemicals such as chlorine, acidified sodium chlorite, peroxyacids, and trisodium phosphate can also be used for decontamination. The use of these substances has been studied in, among others, bovine and pig carcasses (Hugas and Tsigarida 2008).

A range of chemicals are approved to decontaminate meat in the United States and New Zealand. Substances that are used for decontamination include lactic acid, peroxyacetic acid, chlorine dioxide, and acidified sodium chlorite (BEUC 2015).

Decontamination is not allowed within the EU. However, after an official request of the US, only the use of lactic acid is allowed in the EU on bovine carcasses to reduce microbiological contamination (EU 101/2013). In general, the safety of food products is ensured along the whole production chain via prevention, such as on-farm biosecurity, proper transportation conditions, good hygienic practices during slaughter and processing. Decontamination at the end of the animal production chain can disguise unhygienic practices at previous stages. Therefore, in general decontamination should not be used at the expense of hygienic working practices (BEUC 2015).

During the five interviews, we inquired whether decontamination in general takes place in the red meat chain. None of the interviewees were aware of decontamination practices in the Dutch red meat chain; two of them indicated that this is normally not applied in the Netherlands. They indicated that lactic acid was not used for decontamination purposes. Indeed, NVWA reported in 2015 that decontamination with lactic acid of bovine meat was not applied in the Netherlands (NVWA 2015).

Finally, when inspectors were asked about decontamination in the red meat chain, most (9 of the 11) indicated that this topic was unknown for them, they did not reply to this question or they indicated that decontamination was not applied to their knowledge. Of the two remaining inspectors, one indicated the use of UV-lamps in slaughterhouses and cutting places, e.g. for surface decontamination of carcasses. That same inspector also indicated that the use of irradiation was limited, and was specific to chicken.

It can be concluded that because no indications were found for the application of chemical decontamination of carcasses in the Netherlands, no residues due to decontamination are expected in meat products. However, bovine products decontaminated with lactic acid are allowed to be imported into the EU, including the Netherlands. 


\subsection{Residues found in red meat products based on Dutch monitoring data}

ChemKAP data from 2017-2018 showed that 137 samples of various food products collected at slaughterhouses were tested for benzalkonium chloride (BAC) -8, -10, -12, -14, -16, -18 as well as dimethyldioctylammonium chloride (DDAC-08), didecyldimethylammonium chloride (DDAC-10), and didodecyldimethylammonium chloride (DDAC-12). All results were negative (i.e. below LOQ). Samples were collected by the NVWA under the program 'Nationaal Plan Slachtfase', based on a selective sampling strategy. Selective samples are usually taken because of special or risk-oriented interests. Of the 137 samples, $37 \%$ of the samples were taken from the fat of different animals, being goat (1\%), horse $(4 \%)$, pig (15\%), sheep (2\%), and veal calf $(15 \%)$. Another $29 \%$ of the samples were livers of bovine $(13 \%)$, horse $(1 \%)$, pig $(12 \%)$, and sheep $(3 \%)$. Finally, 34\% were taken from the meat of bovine $(12 \%)$, horse $(1 \%)$, pig $(8 \%)$, veal calf $(10 \%)$, and sheep $(3 \%)$.

The KAP database additionally contained five other results for cleaning and disinfection agents. These were for acetic acid in animal fat (type unspecified) from 2002-2003, of which four values were negative, and one value, from 2002 was $10 \mu \mathrm{g} / \mathrm{kg}$ (no MRL for animal fat).

Besides the abovementioned compounds, no data on other chemical compounds indicated in Table 1 were reported. The limited data available in chemKAP on chemical compounds in red meat products showed that no residues of quats were reported on slaughterhouse products. 


\subsection{Cleaning and disinfection in the game meat chain}

\subsubsection{Hygiene protocols and procedures}

\subsubsection{Game meat chain}

The game meat chain consists of free and farmed game. The main difference with the red meat chain is the involvement of hunters for free game, next to farmed game. Furthermore, there are specific NVWA approved establishments for slaughterhouses, cutting plants and processing industries that can handle wild and farmed game meat (NVWA nd).

In general, the NVWA recommends for game meat handling to follow hygiene codes, for example the hygiene code for the catering industry or the hygiene code for poultry (NVWA).

\subsubsection{Hunting}

In case a hunter wants to sell game meat, a statement of game hygiene ("verklaring wildhygiene" or "verklaring van eerste onderzoek") needs to be filled (see Annex 5). This document contains a first part about by who, when and where the game has been shot, which needs to be filled in by the hunter, the second part needs to be filled in by a qualified person who followed the course "game hygiene"; abnormities (e.g. wounds or injuries and abnormalities of organs) of the animal need to be reported in this part of the form. Other organs (except for the gastrointestinal tract need to be present for a proper assessment by this qualified person. In case of swine meat a trichine-research needs to take place, when Trichinella is present the meat cannot be used for consumption. When no abnormalities are observed the animal can be delivered without inclusion of the organs to a processor of game meat (Benelux 2011, NVWA). When abnormalities are observed, and the hunter wants to sell the meat, the animal should be brought (including organs, without gastrointestinal tract) to an approved game processing facility to be checked by the NVWA (NVWA).

\subsubsection{Transport}

It is important to bring game to a cold storage meat as soon as possible; the game is preferably transported in a cold environment. The transport should be hygienic (not further specified). The statement of game hygiene ("verklaring wildhygiene") should be present during transport (NVWA).

\subsubsection{Farmed game animals}

More than half of game meat in Dutch supermarkets is farmed meat, which is often not clearly stated on the label (Dongen 2014). Farmed meat often originates from other European countries or in case of deer from New Zealand (Dongen 2014, ZVVH). No further information about cleaning and disinfection at game farms was found during the literature search.

\subsubsection{Slaughter of farmed game animals, storage and processing of game meat}

Hygiene rules and sampling frequency for microbiological analyses during slaughter and processing of game meat are the same as the hygiene rules for farm animals as set in Regulation (EC) No 852/2004 on the hygiene of foodstuffs and Regulation (EC) 853/2004 laying down specific hygiene rules for food of animal origin. Specific microbiological criteria on meat products are laid down in Regulation (EC) No $2073 / 2005$.

\subsubsection{Results of interviews game meat chain}

In total, 11 invitations for interviews were sent. Seven persons responded, of which one indicated that he/she had too limited knowledge to contribute to this study and one person answered to part of the questions via email. Five persons were interviewed. In total, six relevant responses (five interviews and one email response) were included in this study (55\%). Two persons were involved in hunting and four persons were butchers or involved in processing of game meat. Hunters that were interviewed indicated that shot game animals which live freely on the Veluwe national park are processed by a local butcher. People involved in the primary phase of farmed game animals did not respond to frequent invitations for interviews, therefore no information on game farms is included in this section. 
Processors of game meat, included in this study, process amongst others wild boar, deer, rabbit, duck and goose. The processes conducted are boning, brining and smoking. Products made are sausages, meat filet, hamburgers and smoked duck breast.

The following section describes the results of the interviews.

\subsubsection{Hunting}

A first quality check in the game meat chain is performed by the hunter right after the animal is shot. This quality check consists of a visual inspection on the health status of the animal. In case there are ulcers or any other indications that the animal may not have been well, the animal will not be processed as meat for human consumption. Instead, the animal is left where it is shot for biological and natural degradation in nature. At the place of the hunt, the hunter also removes the complete gastro-intestinal tract. In case the shot has gone through the gastro-intestinal tract, the whole animal should be checked for possible contamination from the content of the intestines. Contaminated meat should be removed. The hunter uses a knife to open the large game animal, cutting out the gastrointestinal tract and other organs (kidneys and liver) and possible contaminated parts of the animal. Bones of the animal are sawed in order to get access to the organs. In case of large game animals all organs (including liver and kidneys) will be removed, for small game animals the organs will be removed by the processors. The utensils are cleaned after each animal with a solution of water and all-purpose cleaning agent, rinsed with water, sprayed with a disinfectant and air-dried. The disinfectant spray has the active ingredient sodium hypochlorite in concentrations up to $0.07 \%$ and rinsing with water afterwards is not needed according to the product instructions.

\subsubsection{Transport and cooling}

After the first visual inspection and the removal of organs by the hunter, the animal is quickly transported from the place of the hunt to a cooling cell. This can occur in the tailgate of a pick-up truck or in a special box for wild. During this short transportation, the animal is not covered and the animal lays with the open side up, so that it can be air-dried and does not contaminate the truck. After the transport of an animal, the truck is cleaned with a solution of water and an all-purpose cleaner and afterwards the water is removed or it is air-dried. The animal should be cooled within 30 minutes after it has been shot and the temperature in the cooling cell is $3^{\circ} \mathrm{C}$. In the cooling cell, the animal is hanged on gambrels. The animal will be picked up by the processer, who will inspect the animal again in the cooling cell. The animal is cold transported from hunter to processor. After the animal is picked up from the hunter, the cooling cell is cleaned with a solution of water and all-purpose cleaning agent and afterwards it is air-dried. Besides, an odour remover (the product "Powersmell") (see Table 8) is sprayed into the cooling cell as mentioned in one interview.

\subsubsection{Slaughter of farmed game animals, storage and processing of game meat}

Similar to the hunter, the processor also conducts visual inspections to check the overall hygiene and health status of the animal. At a professional processor, the veterinary inspector of NVWA checks the animals before they enter the processing facility. The frequency of these checks are for large game animals, such as wild boar and deer, at each incoming animal. For small game animals, such as goose and rabbit, the checks are on a number of animals per incoming batch.

In case organs of the gastro-intestinal tract are damaged, and there is a high risk of contamination of the meat, contaminated meat cannot be used for human consumption. Parts of the animal, which are suspected to be contaminated, are removed. A small not professional processor (only for own consumption), indicated that he rinses the meat with water. He explained that this is also done by slaughterhouses. While another processor and hunter explained that rinsing of the game meat should be avoided, because it stimulates the growth of microorganisms. Two processors explained that rinsing of the meat with water is sometimes performed in case the meat of the game animal is heavily covered in blood. This blood can also stimulate growth of microorganisms. During skinning of small game animals, such as rabbits, the animals can become heavily covered in blood. So in this case rinsing with water would be a solution to prevent outgrowth of microorganisms. The processors will only rinse in the beginning of the process and not at the end, when the product is almost finished. One processor strongly requests the hunters not to do this themselves. In case the processor observes much blood on the meat, he carries out the rinsing himself. He feels much more confident that in this 
way it is carried out correctly and there is no invisible contamination. He also added that rinsing with water of meat is common practice in Germany.

The small not professional processor explained that he removes parts of the animal with visual contamination (e.g. grass is observed). After these acts, the processor washes his hands with a regular disinfecting soap of the brand Unicura. The tables, which are worked on, are cleaned with a solution of sodium hypochlorite (approximately 5\%) and afterwards rinsed with water. As earlier described, at hunting-level a biocidal spray is used with sodium hypochlorite, which is not needed to be rinsed with water afterwards. The concentrations of these biocidal products are different $(\leq 0.07 \%$ versus $\sim 5 \%$ ). The utensils are cleaned with a solution of water and dish soap. Also, the utensils are rinsed with water after cleaning. When an animal is not shot properly and the gastro-intestinal tract has been hit, these cleaning steps of the utensils are carried out continuously during their use.

Three professional processors or butchers indicated that cleaning and disinfection agents and procedures for game meat are comparable to the procedures and products used for red meat.

A processor explained that the frequency of cleaning and disinfecting utensils, such as knives, depends on the type of process in which they are used. The utensils that are used during skinning are cleaned and disinfected more frequently than those used during cutting of meat filets. The utensils are disinfected in a steriliser, which consists of a bath with constant hot water. However, some challenges are found at this step in the cleaning and disinfection procedure. The steriliser sometimes fails in reaching the right temperature, or is defect and has to be repaired or replaced immediately. Further, the utensils should be washed with water before entering the steriliser, but there is not always sufficient time for this, resulting in fouling in the steriliser. For these reasons, the processor is looking for alternatives and is experimenting with disinfecting the utensils with a disinfectant on the basis of lactic acid. This processor is also experimenting with the disinfectant Nocolyse (based on hydrogen peroxide), which can be sprayed in the room and disinfects everything that has come in contact with the spray. It is expected that no residues of hydrogen peroxide, because of the properties of this substance will be left behind and therefore rinsing with water afterwards would not be necessary. Nowadays, the processor uses a regular cleaning agent for professional use. These agents are mixed by a professional, external cleaning team in the correct concentrations and applied with a high pressure hose. An agent on the basis of sodium hypochlorite is used for disinfection. The prescribed application times of these agents are between 5 and 10 minutes, but the processor applies 20 minutes. In this way, the needed application time is guaranteed. After cleaning and disinfection, the whole premises is rinsed with water. The professional, external cleaning team is trained to use the agents in the correct way and perform the routine every day after the production is finished. In some cases, the frequency of cleaning and disinfection in the processing facility is higher than once a day. For example, when the process switches from conventional meat to organic meat, the process line is cleaned and disinfected in between by the processing operators. Processing operators wash their hands with a soap for professional use. An external quality expert checks twice a month if the cleaning and disinfection has been carried out properly; the expert also checks on possible residues and if possible new agents are correct to use. Once a year, this expert checks if the administration on the cleaning and disinfection agents is still up-to-date.

Another processor also uses a steriliser for the disinfection of utensils where possible. When it is not possible to use a steriliser, a disinfectant on the basis of lactic acid is used for utensils. The frequency of these routines for utensils is after each animal. For the cleaning and disinfection of the rooms, tables and cooling cell, the agents are mixed automatically with water and applied with a high pressure hose. After the agents are applied, the operators take a coffee break, so when they come back the minimum application time of the agents has passed. The last step in the cleaning and disinfection routine at this processor is also rinsing with water, with an exception for the use of lactic acid where it is not needed to rinse. Each quarter of the year, environmental samples are taken at the premises and checked if cleaning and disinfection are carried out correctly. When these checks show that it is carried out incorrectly, the frequency of the checks will be augmented.

Another processor explained there is not a difference in the cleaning and disinfection of farmed game meat or free game meat per se, since it will remain a challenge to keep the total viable count of microorganisms as low as possible. However, free game animals have a higher total viable count from the 
start already. This is due the fact that the living environment of free game animals is not controlled and animals come in contact with a more diverse microflora. Besides, the free game animals are shot in nature; therefore, the probability of contamination within the animal is higher than when the animal is killed in a more controlled manner. This processor applies the same hygiene protocol from Koninklijk Nederlandse Slagersbond (KNS; Royal Dutch Butcher alliance) for all the production processes on his premises, where regular meat is handled and sold as well as game meat. This processor indicated that he does not decontaminate the products. He has heard that some hunters use apple vinegar to decontaminate the meat; however, this is mostly for personal consumption.

It is noticed by processors that there is much deviation in the level of hygiene at the hunters-level. As described earlier, hunters are the first step in the game meat chain, where visible checks are carried out. However, one relies on expert judgement at this point. Besides, it is hard for the processors to check if procedures are carried out correctly. Like for example when rinsing with water: if the hunter did this, the animal and the meat may look proper for human consumption, but there may be a high invisible contamination level. The processors indicate that at the hunters-level improved is possible.

An overview of active ingredients used for cleaning and disinfection as indicated during the interviews can be found in Table 8.

Table 8 Active ingredients and their application during cleaning and disinfection per part of the game meat chain as indicated during the interviews

\begin{tabular}{|c|c|c|c|c|c|c|}
\hline \multirow[b]{2}{*}{ Active ingredient or product } & \multirow[b]{2}{*}{$\begin{array}{l}\text { Additional } \\
\text { information* }\end{array}$} & \multirow[b]{2}{*}{ Application } & \multicolumn{4}{|c|}{$\begin{array}{c}\text { Part of the game meat } \\
\text { chain }\end{array}$} \\
\hline & & & 을 & $\frac{t}{\frac{1}{0}}$ & $\begin{array}{l}\frac{0}{0} \\
\frac{1}{6} \\
\frac{8}{4} \\
\frac{0}{8}\end{array}$ & $\frac{0}{\frac{2}{5}}$ \\
\hline Hand soap (not specified) & Cleaning agent & Employees (hands) & $x$ & $x$ & $x$ & $x$ \\
\hline $\begin{array}{l}\text { Hand soap (sodium laureth sulfate, lauryl } \\
\text { glucoside, PEG-7 glycerol cocoate, sodium } \\
\text { benzoate, laureth-2, propylene glycol, PEG-55 } \\
\text { and propylene glycol oleate) }\end{array}$ & Cleaning agent & Employees (hands) & & & & $x$ \\
\hline All-purpose cleaning agent & Cleaning agent & Materials & $x$ & $x$ & $x$ & $x$ \\
\hline $\begin{array}{l}\text { Cleaning agent (potassium hydroxide, sodium } \\
\text { hydroxide, phosphoric acid, 2- (2- } \\
\text { butoxyethoxy) ethanol, amines and C12-14 } \\
\text { alkyl dimethyl, N-oxides) }\end{array}$ & Cleaning agent & Materials, floor and walls & & & & $x$ \\
\hline Lactic acid & Approved biocide & Utensils & & & & $x$ \\
\hline Sodium hypochlorite & Approved biocide & Materials & $x$ & $x$ & $x$ & $x$ \\
\hline \multirow[t]{2}{*}{ Same ingredients as used for red meat } & Approved biocides & Employees (e.g., hands) & & & $x$ & $x$ \\
\hline & and cleaning agents & Materials, floor and walls & & & $x$ & $x$ \\
\hline $\begin{array}{l}\text { Powersmell; propaan-2-ol, 1-Heptanol 2- } \\
\text { propyl- 7EO, 3-methyl-4-(2,6,6-trimethyl2- } \\
\text { cyclohexeen-1-yl)-3-buteen-2-on) }\end{array}$ & Odour remover & Materials, floor and walls & & & $x$ & \\
\hline
\end{tabular}

\subsubsection{Conclusions on the game meat chain}

Overall, it can be concluded that cleaning and disinfection procedures during slaughter, storage and processing of game meat are comparable to those used for red meat. Cleaning or disinfection procedures applied during hunting and in case of processing for private use may differ. Processors mentioned that hygiene procedures at hunter level could be improved. It is not desired by the processors that the game meat is washed with water, since it can hide contamination and could disperse the present contamination. It is difficult for processors to check if procedures at hunters levels were performed in the right way. However, cleaning and disinfection products were indicated to be used in the right way in this study and procedures were followed. Conclusions on possible residues due to cleaning and disinfection products are not different for the game meat supply chain compared to the red meat supply chain. 


\section{Discussion}

\subsection{Authorised biocidal products}

In the Netherlands, authorised PT1, PT3, PT4 products are not restricted to a specific type of animals. Therefore, these products are not specifically authorised to be used in the red meat or game meat chain. Only for some specific biocidal products an application for a specific animal species has been mentioned. This hampered the analyses of biocidal products for the supply chains studied.

Nevertheless, the inventory of authorised biocidal products allowed to provide an overview of active ingredients that may be used for hand hygiene, or for disinfection at primary production or subsequent steps in the red meat and game meat supply chain.

\subsection{Active ingredients in cleaning and disinfection products}

The list of active ingredients that often occurs in authorised disinfection products corresponds with the active ingredients which are used in practice in the red meat chain as reported in the questionnaires and interviews.

In hygiene protocols, the type of cleaning or disinfection products to be used are often not specified. The literature in professional magazines mainly reported experiences of food processors applying new cleaning and disinfection products. Examples thereof are products with the active ingredients hydrogen peroxide and the physical disinfection method with carbon dioxide $\left(\mathrm{CO}_{2}\right)$ applied as dry ice.

The active ingredients used in the red meat and game meat chain, as indicated in the literature, questionnaires, and interviews are all authorised ingredients. Only the biocide database (RIVM 2012) showed products on the market in 2011, containing active ingredients that were not or no longer authorised. However, it is not known whether these products were actually used. Since 2011, online sale in general has increased tremendously. These products may contain unauthorised active ingredients or green alternatives for currently applied biocidal products. However, a search on online sale of cleaning and disinfection products was not part of this study.

\subsection{Hygiene protocols and cleaning and disinfection practices}

For primary production, in the red meat chain, no hygiene protocols were available. This finding corresponds with the information from the interviews and questionnaires that cleaning and disinfection with agents is not a standard daily routine. In the case of incidences or when the barn is empty, cleaning and disinfection products can be used; often cleaning and disinfection is then carried out by an external company.

There are several instructions and protocols for the transport phase available, and a handbook established by the NVWA should be followed at approved cleaning and disinfection sites (R\&Oplaatsen). Truck drivers need to change clothes and cleaning and disinfection should always take place after something or someone has come into contact with the animals. However, the interviews and questionnaires show that cleaning and disinfection in the transport phase is a challenge. It is not always possible or can only be performed insufficiently because resources and facilities are limited or unavailable. However, the frequency of cleaning during transport also depends on the type of transport, as some respondents were only involved in the transport of packaged foods and not in the transport of live animals. 
Since 2015, the NVWA more strictly monitors compliance with hygiene protocols and regulation in slaughterhouses. Between 2015 and 2018, the average compliance on cleaning and disinfection was 83\% (NVWA 2019). Nevertheless, NVWA inspectors indicated that cleaning and disinfection in general is not a priority during inspection but only when there is a specific reason to focus on such practices. Some of the NVWA inspectors acknowledged that they do not have detailed knowledge of cleaning and disinfection. Furthermore, they also indicated that knowledge about cleaning and disinfection at both small and large companies is limited. NVWA inspectors indicated that smaller companies might make use of "normal" household cleaning or disinfection products. These could contain non-approved active ingredients, as it was shown in 2019 that $60 \%$ of hand disinfectants on the consumer market were not approved by the Ctgb (NVWA 2019).

The responses of slaughterhouses during the interviews and questionnaires were detailed, and respondents referred to hygiene protocols and regulation. However, from the questionnaires and interviews it appeared that smaller slaughterhouses could have less detailed hygiene codes or may have less knowledge about cleaning and disinfection. They sometimes indicated less frequent cleaning and disinfection schedules, which could also be related to the less frequent use of the materials and facilities. Furthermore, for smaller companies, cleaning and disinfection should be part of the daily tasks of the personnel, while larger companies can afford in-house specialists on cleaning and disinfection that perform e.g. analytical checks of disinfection performance.

In general, according to those working in the supply chain, cleaning and disinfection (during phase II and phase III) are performed by trained, designated, internal or external personnel. Hygiene protocols and instructions are followed. Those involved at the slaughterhouse, cutting plant, cold storage (phase II), as well as processing (phase III), usually invest in keeping their knowledge and expertise up to date.

The questionnaires and interviews revealed several challenges related to cleaning and disinfection. One of these is the possible resistance of microorganisms against biocidal products. Furthermore, another challenge is that the machinery can sometimes only be minimally cleaned between processing, in between product changes the line is rinsed. Also, some part of the machinery is very difficult to clean due to poor hygienic design. Sterilisation of utensils by a steriliser is not always functioning optimal, therefore processers are interested in alternatives. This shows that the challenges encountered focus on microbiological food safety rather than on chemical food safety.

\subsection{Residues}

Respondents from the interviews and questionnaires were often not aware of possible concerns for human health from the use of cleaning and disinfection agents. Alcohols, quats, and the by-products of chlorine-based products, like chlorate, were indicated by some respondents to be of possible human health concern. However, rinsing is normally performed and should remove all residues. Nevertheless, NVWA inspectors mentioned that given time limitations, instructions for the use and application of agents are rarely read by users.

Overall, when protocols and instructions are followed appropriately, no residues of cleaning and disinfection agents are expected in food products. Indeed, the limited monitoring data available showed that slaughterhouse products contained no quats residues. However, insufficient cleaning and disinfection procedures could occur due to limited knowledge or time limitations. It is, therefore, relevant to monitor on the possible presence of residues of cleaning and disinfection agents. The main used active ingredients for disinfection were alcohol-based compounds, chlorine-based compounds (mainly sodium hypochlorite), DDAC, hydrogen peroxide, and peracetic acid. Residues in food are not expected for the volatile alcohol-based compounds, hydrogen peroxide and peracetic acid. Therefore, especially, monitoring of by-products formed by using chlorine-containing products and of quaternary ammonium compounds is relevant in the red-meat and game meat chain. 


\section{Main conclusions and recommendations}

\section{$5.1 \quad$ Conclusions}

- Active ingredients in biocidal products that can be applied in the red meat chain mainly include alcohol-based compounds, chlorine-based compounds (mainly sodium hypochlorite), DDAC, hydrogen peroxide, and peracetic acid. Hand soap, potassium hydroxide, and sodium hydroxide are often used for cleaning throughout the red meat chain. Applications of the active ingredients used for cleaning and disinfection per part of the red meat are indicated in Table 6. Cleaning and disinfection agents used in the game meat chain are comparable to the agents used for red meat.

- The active ingredients used in the red meat and game meat chain for disinfection, as indicated in the literature and the interviews and questionnaires, are all authorised ingredients (an overview of authorised active ingredients can be found in Table 2). Although the database of from the RIVM of used biocides showed that products on the market in 2011 contained active ingredients that are currently not authorised (see Table 5), the actual use of these ingredients is unknown.

- People involved in the red meat and game meat chain are aware of the importance of and hygiene protocols and regulations related to cleaning and disinfection. However, sometimes less knowledge about this was observed in smaller companies compared to larger companies. Insufficient cleaning and disinfection procedures could occur in all parts of the chain due to insufficient knowledge or time limitations. This may include the use of cleaning and disinfection products, which could lead to residues in food products.

- Monitoring data of samples collected at slaughterhouses (2017-2018) showed that no quats were found in red meat products $(n=137)$; there were no data available for other active ingredients present in cleaning and disinfection products.

- No indications were found for the application of chemical decontamination of carcasses in the Netherlands. Lactic acid is used for other applications (materials, floors or walls) in the red meat and game meat chain. Import of meat decontaminated with lactic acid is allowed. Rinsing of game meat can be performed with water, but when improperly applied this could lead to contamination with microorganisms.

- Overall, the focus on food safety related to cleaning and disinfection is more on microbiological food safety than on chemical food safety.

\subsection{Recommendations}

- Education and training should continue in all parts of the chain to create awareness of safe practices, especially for primary production, hunting, transport, and for smaller companies in general.

- Current (online) availability of unauthorised and alternative products on the market and actual use of these products should be studied in more detail. An option would be to develop a search engine for this to find unauthorised and alternative products with potential risks, using social and official media, and scientific literature. With the use of machine learning techniques this information could be collected fast and automatically. WFSR could support NVWA in developing such a search engine.

- Monitoring of residues of cleaning and disinfection agents is limited; therefore, monitoring of the frequently used active ingredients in the red meat and game meat chain which could possibly be present in food products should be increased. This should include by-products formed by the use of chlorine-containing products and quaternary ammonium compounds. 


\section{References}

Anonymous. (2020). "Model Hygiëneprotocol voor de Arbocatalogus Vlees werkt." Retrieved 03/06/2020, from https://docplayer.nl/15597944-Model-hygieneprotocol-voor-de-arbocatalogusvlees-werkt.html.

Banach, J. L., Hoffmans, Y., van Asselt, E.D., Klüche, M., Hoek - van den Hil, E.F. (2020). "Cleaning and disinfection in the poultry, eggs, leafy greens and sprouts supply chains." Wageningen, Wageningen Food Safety Research, WFSR report 2020.008. 92 pp.; 0 fig.; 11 tab.;188 ref.

Benelux (2011). Wildhygiëneregels in de Benelux. T. I. M. e. E. U. S.-G. v. d. Benelux.

BEUC. (2015). "Factsheet Meat decontamination." Retrieved 25/05/2020, 2020, from https://www.beuc.eu/publications/beuc-x-2015015_meat_decontamination_treatments_factsheet.pdf.

Brandl, M. T., B. M. Rosenthal, A. F. Haxo and S. G. Berk (2005). "Enhanced survival of Salmonella enterica in vesicles released by a soilborne Tetrahymena species." Applied and Environmental Microbiology 71(3): 1562-1569.

COV. (2018). "Voedselveiligheid in de Nederlandse vleesindustrie." Retrieved 03/06/2020, from https://www.youtube.com/watch?v=u_lvIOdHAXA\&feature=youtu.be.

Ctgb. (2020). "Toelatingendatabank." Retrieved 06/04/2020, from https://toelatingen.ctgb. $\mathrm{nl} / \mathrm{nl} /$ authorisations.

Dongen, v. A. (2014). "Hertenbiefstuk en eendenborstfilet meestal niet echt wild." Retrieved 07/07/2020, 2020, from https://www.bndestem.nl/overig/hertenbiefstuk-en-eendenborstfiletmeestal-niet-echt-wild a10321cf/?referrer=https://www.google.com/.

Expertisecentrum Voedingsmiddelenindustrie (2019). Schone slacht - Hygiëne roodvleesslachthuizen in de lift.

GrollemanColdstores (2020). Schoonmaakplan en matrix.

Hugas, M. and E. Tsigarida (2008). "Pros and cons of carcass decontamination: The role of the European Food Safety Authority." Meat Science 78(1): 43-52.

NVWA (2015). "Risicobeoordeling roodvleesketen. Rund, varken, paard, schaap en geit. Advies van bureau Risicobeoordeling \& onderzoeksprogrammering (BuRO)."

NVWA. (2019). "Hygiëne in grote roodvlees slachthuizen juli 2015 t/m juni 2018." Retrieved 24/06/2020, from https://www.nvwa.nl/onderwerpen/inspectieresultaten-grote-roodvleesslachthuizen/naleving-hygiene-in-grote-roodvlees-slachthuizen.

NVWA. (2019). "NVWA: Slechts $13 \%$ onderzochte handdesinfectiemiddelen voldoet aan wettelijke eisen." NVWA Nieuwsbericht, from https://www.nvwa.nl/nieuws-enmedia/nieuws/2019/04/16/nvwa-slechts-13-onderzochte-handdesinfectiemiddelen-voldoet-aanwettelijke-eisen.

NVWA. (nd). "Erkende R\&O-plaats." Retrieved 08/06/2020, from https://www.nvwa.nl/onderwerpen/reinigen-en-ontsmetten-van-vervoer-en-transportmiddelen/ro-plaatsen/erkende-r-o-plaats.

NVWA. (nd). "List of approved food establishments." Retrieved 20/08/2020, 2020, from https://english.nvwa.nl/topics/approved-establishments/food-establishments.

NVWA. (nd). "Wild." Retrieved 19/082020, 2020, from https://www.nvwa.nl/onderwerpen/wild.

NVWA. (nd). "Wild inkopen bij jagers." Retrieved 19/08/2020, 2020, from https://www.nvwa.nl/onderwerpen/wild/wild-inkopen-bij-jagers.

RIVM (2008). Landelijk Centrum Hygiëne en Veiligheid Checklist Keukenhygiëne Horeca.

RIVM (2012). "Database biocidengebruik in verschillende bedrijftypes: Inventarisatie van toegelaten en niet-toegelaten middelen." RIVM Briefrapport 609021120/2012.

Vakblad Voedingsindustrie (2017). Effectieve innovatie Havatec en T. Boer \& Zn kwaliteitsgarantie dankzij hygiënesluis.

Veelogistiek (nd). Algemeen Protocol voor transporteur/chauffeur bij transport en laden en lossen ter voorkoming van besmetting met pathogene virussen zoals Afrikaanse Varkenspest (AVP).

Vlees. (nd). "Over het slachtproces en de productie van vlees." Retrieved 03/06/2020, from https://www.vlees.nl/themas/van-vee-naar-vlees/slachtproces/. 
Vlees+. (2012). "Uw vlees in veilige bakken van Schiphorst." Retrieved 19/05/2020, from https://www.vleesplus.nl/nieuws/uw-vlees-in-veilige-bakken-van-schiphorst.

Vlees+. (2018). "Hygiënecontrole bij hergebruik kratten onder de maat." Retrieved 19/05/2020, from https://www.vleesplus.nl/nieuws/hygienecontrole-bij-hergebruik-kratten-onder-de-maat.

Vleesmagazine. (2012). "Hogedrukspuit verhoogt kans op Listeria." Retrieved 29/04/2020, from https://www.vleesmagazine.nl/industrienieuws/nieuws/2012/08/hogedrukspuit-verhoogt-kans-oplisteria-10114917.

Vleesmagazine. (2012). "Hogere resistentie Salmonella tegen chemische reiniging." Retrieved 29/04/2020, from https://www.vleesmagazine.nl/industrienieuws/nieuws/2012/08/hogereresistentie-salmonella-tegen-chemische-reiniging-10121441.

Vleesmagazine. (2013). "Hulp vleeswarenbedrijven bij monitoren Listeria." Retrieved 29/04/2020, from https://www.vleesmagazine.nl/industrienieuws/nieuws/2013/04/hulp-vleeswarenbedrijvenbij-monitoren-listeria-1018118.

Vleesmagazine. (2015). "Goed reinigbaar transportbandsysteem voor voedselindustrie." Retrieved 29/04/2020, from https://www.vleesmagazine.nl/marktberichten/nieuws/2015/04/goedreinigbaar-transportbandsysteem-voor-voedselindustrie-10138078.

Vleesmagazine. (2018). "VMT Food Safety Event kijkt of borging afdoende is." Retrieved 29/04/2020, from https://www.vleesmagazine.nl/nieuws/nieuws/2018/10/vmt-food-safety-event-kijkt-ofborging-afdoende-is-10148357.

Vleesmagazine. (2019). "Ctgb: 'Inwerkingstijd bij desinfectiemiddelen luistert nauw'." Retrieved 29/04/2020, from https://www.vleesmagazine.nl/industrienieuws/nieuws/2019/10/ctgbinwerkingstijd-bij-desinfectiemiddelen-luistert-nauw-10150469.

Vleesmagazine. (2019). "Ctgb: 'Inwerkingstijd bij desinfectiemiddelen luistert nauw'." Retrieved 30/04/2020, from https://www.vleesmagazine.nl/industrienieuws/nieuws/2019/10/ctgbinwerkingstijd-bij-desinfectiemiddelen-luistert-nauw-10150469.

Vleesmagazine. (2019). "Nieuwe stoomtransportbandreiniger voor schakelbanden." Retrieved 29/04/2020, from https://www.vleesmagazine.nl/industrienieuws/nieuws/2019/10/nieuwe-stoomtransportbandreiniger-voor-schakelbanden-10150289.

VMT. (2019). "Droogijsstralen krijgt bredere toepassing bij verwijderen vuil." Retrieved 08/04/2020, from https://www.vmt.nl/algemeen/nieuws/2019/01/droogijsstralen-krijgt-bredere-toepassingbij-verwijderen-vuil-10135786.

VMT. (2020). "Meer vraag naar desinfectiemiddelen en extra schoonmaakrondes in voedingsindustrie door coronavirus." Retrieved 09/04/2020, from https://www.vmt.nl/technologietechniek/nieuws/2020/03/meer-vraag-naar-desinfectiemiddelen-en-extra-schoonmaakrondes10140788.

Voedingsindustrie, V. (2015). "Desinfecteren met zuurstof radicalen." Retrieved 15/04/2020, from https://vakbladvoedingsindustrie. $\mathrm{nl} / \mathrm{nl} /$ artikel/desinfecteren-met-zuurstof-radicalen.

Voedingsindustrie, V. (2017). "Hoe zet je een veilig product in de markt?" Retrieved 15/04/2020, from https://vakbladvoedingsindustrie.nl/nl/artikel/hoe-zet-je-een-veilig-product-in-de-markt.

Voedingsindustrie, V. (2018). Desinfecterende damp doodt bacteriën. Vakblad Voedingsindustrie.

Voedingsindustrie, V. (2018). "Zweistra wil bedrijfszekerheid." Retrieved 15/04/2020, from https://vakbladvoedingsindustrie.nl/nl/artikel/zweistra-wil-bedrijfszekerheid.

Voedingsindustrie, V. (2019). Blockland cold stores kiest voor Nocotech optimale veiligheid. Vakblad Voedingsindustrie.

Voedingsindustrie, V. (2019). "Weinig toevoegingen bij Chateau Briand." Retrieved 15/04/2020, from https://vakbladvoedingsindustrie.nl/nl/artikel/weinig-toevoegingen-bij-chateau-briand.

ZVVH. (nd). "Wild en gevogelte." Retrieved 07/07/2020, 2020, from https://www.zvvh.nl/nl/wild-engevogelte. 


\title{
Annex 1 Questionnaires red meat chain
}

\author{
WAGENINGEN
}

UNIVERSITY \& RESEARCH

\section{Vragenlijst - Reiniging \& desinfectie in de roodvleesketen - primaire sector en transport}

Voor welke schakel in de roodvleesketen vult u deze vragenlijst in?

\author{
$\square$ Boerderij \\ $\square$ Transport \\ $\square$ Anders, namelijk: Click or tap here to enter text.
}

1. Wat is de belangrijkste reden om schoon te maken of te desinfecteren op de boerderij of tijdens transport? Click or tap here to enter text.

2. Welke actieve stoffen worden gebruikt voor reiniging en desinfectie van:

a. Stallen (bijv. wanden/vloeren) Click or tap here to enter text.

b. Materialen in de stal Click or tap here to enter text.

c. Transportkratten/transportmaterialen Click or tap here to enter text.

d. Medewerkers (bijv. handen) Click or tap here to enter text.

3. Hoe vaak wordt er met deze middelen schoongemaakt of gedesinfecteerd? Click or tap here to enter text.

4. Welke actieve ingrediënten voor reiniging en desinfectie kunnen een potentieel gevaar opleveren voor de volksgezondheid indien residuen in het product terechtkomen (bv. Door de productie van bijproducten)? Click or tap here to enter text.

5. Hoe wordt het juiste gebruik van de middelen geborgd?

a. Wordt er altijd gereinigd voor desinfectie? Zo nee, wanneer niet? Click or tap here to enter text.

b. Wordt er altijd gespoeld na reiniging of desinfectie? Zo nee, wanneer niet? Click or tap here to enter text.

c. Hoe wordt ervoor gezorgd dat de minimale inwerkingsduur aangehouden wordt? Click or tap here to enter text.

d. Hoe wordt ervoor gezorgd dat de juiste concentratie toegepast wordt? Click or tap here to enter text.

e. Hoe wordt ervoor gezorgd dat de juiste middelen voor de juiste toepassing gebruikt worden? Click or tap here to enter text.

f. Hoe wordt voorkomen dat niet-toegelaten stoffen gebruikt worden? Click or tap here to enter text.

g. Zijn er procedures om het reinigen of desinfecteren te controleren? Hoe gaat dit in zijn werk? Click or tap here to enter text.

h. Waar haalt $\mathrm{u}$ informatie vandaan over reiniging en desinfectie op uw bedrijf? Heeft $\mathrm{u}$ behoefte aan meer informatie? Click or tap here to enter text. 


\title{
Vragenlijst - Reiniging \& desinfectie in de roodvleesketen - slachterij, uii koel- en vrieshuis, verwerking
}

Voor welke schakel in de roodvleesketen vult u deze vragenlijst in?

\author{
$\square$ Transport \\ $\square$ Slachterij \\ $\square$ Uitsnijderij \\ $\square$ Koelhuis \\ $\square$ Verwerking \\ $\square$ Anders, namelijk: Click or tap here to enter text.
}

1. Wat is de belangrijkste reden om schoon te maken of te desinfecteren tijdens de slack of verwerking van rood vlees?

Click or tap here to enter text.

2. Welke actieve stoffen worden gebruikt voor reiniging en desinfectie van:

a. Medewerkers (bijv. handen); Click or tap here to enter text.

b. Slachterij, uitsnijderij, koel- en vrieshuis (vloeren/wanden); Click or tap here text.

c. Materialen in de slachterij/uitsnijderij/koel- en vrieshuis die in aanraking kom voedingsproduct; Click or tap here to enter text.

3. Hoe vaak wordt er met deze middelen schoongemaakt of gedesinfecteerd? Click or tap here to enter text.

4. Welke actieve ingrediënten voor reiniging en desinfectie kunnen een potentieel gevaaı voor de volksgezondheid indien residuen in het product terechtkomen (bv. de product bijproducten)?

Click or tap here to enter text.

5. Hoe wordt het juiste gebruik van de middelen geborgd?

a. Wordt er altijd gereinigd voor desinfectie? Zo nee, wanneer niet? Click or tap enter text.

b. Wordt er altijd gespoeld na reiniging of desinfectie? Zo nee, wanneer niet? Cli here to enter text.

c. Hoe wordt ervoor gezorgd dat de minimale inwerkingsduur aangehouden wor tap here to enter text.

d. Hoe wordt ervoor gezorgd dat de juiste concentratie toegepast wordt? Click o to enter text.

e. Hoe wordt ervoor gezorgd dat de juiste middelen voor de juiste toepassing g $\epsilon$ worden? Click or tap here to enter text.

f. Hoe wordt voorkomen dat niet-toegelaten stoffen gebruikt worden? Click or ti enter text.

g. Zijn er procedures om het reinigen of desinfecteren te controleren? Hoe gaat werk? Click or tap here to enter text.

h. Waar haalt u informatie vandaan over reiniging en desinfectie op uw bedrijf? behoefte aan meer informatie? Click or tap here to enter text. 


\section{Vragenlijst - Reiniging \& desinfectie in de roodvleesketen - leveranciers}

Voor welke schakel in de roodvleesketen vult u deze vragenlijst in?

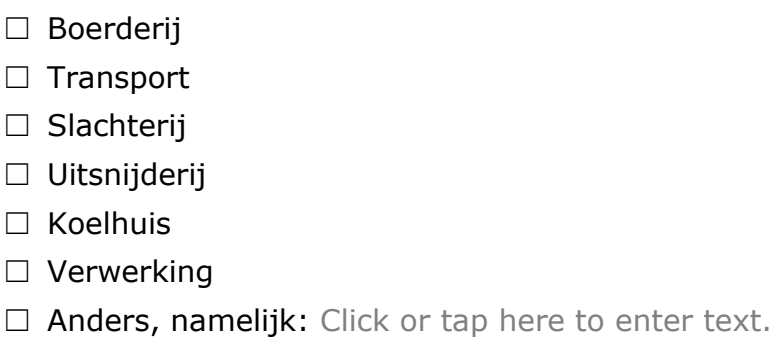

1. Wat is de belangrijkste reden om schoon te maken of te desinfecteren in de roodvleesketen?

Click or tap here to enter text.

2. Welke actieve stoffen worden gebruikt voor reiniging en desinfectie van:

a. Medewerkers (bijv. handen) Click or tap here to enter text.

b. Vloeren en/of wanden van de boerderij, slachterij, uitsnijderij, koel- en vrieshuis etc Click or tap here to enter text.

c. Materialen in/op de boerderij, slachterij, uitsnijderij, koel- en vrieshuis die in aanraking komen met het voedingsproduct Click or tap here to enter text.

3. Hoe vaak wordt er met deze middelen schoongemaakt of gedesinfecteerd? Click or tap here to enter text.

4. Welke actieve ingrediënten voor reiniging en desinfectie kunnen een potentieel gevaar opleveren voor de volksgezondheid indien residuen in het product terechtkomen (bv. de productie van bijproducten)?

Click or tap here to enter text.

5. Hoe wordt het juiste gebruik van de middelen geborgd?

a. Wordt er altijd gereinigd voor desinfectie? Zo nee, wanneer niet? Click or tap here to enter text.

b. Wordt er altijd gespoeld na reiniging of desinfectie? Zo nee, wanneer niet? Click or tap here to enter text.

c. Hoe wordt ervoor gezorgd dat de minimale inwerkingsduur aangehouden wordt? Click or tap here to enter text.

d. Hoe wordt ervoor gezorgd dat de juiste concentratie toegepast wordt? Click or tap here to enter text.

e. Hoe wordt ervoor gezorgd dat de juiste middelen voor de juiste toepassing gebruikt worden? Click or tap here to enter text.

f. Hoe wordt voorkomen dat niet-toegelaten stoffen gebruikt worden? Click or tap here to enter text.

g. Zijn er procedures om het reinigen of desinfecteren te controleren? Hoe gaat dit in zijn werk? Click or tap here to enter text. 


\title{
Annex 2 Interviews red meat chain
}

WAGENINGEN

UNIVERSITY \& RESEARCH

\section{Interview Reiniging \& desinfectie in de roodvleesketen}

1. Kunt u wat meer vertellen over uw bedrijf/organisatie?

2. Voor welke schakel in de roodvleesketen kunt u de vragen beantwoorden?

\author{
$\square$ Boerderij \\ $\square$ Transport \\ $\square$ Slachterij \\ $\square$ Uitsnijderij \\ $\square$ Koelhuis \\ $\square$ Verwerking \\ $\square$ Anders, namelijk: Click or tap here to enter text.
}

3. Wat is de belangrijkste reden om schoon te maken of te desinfecteren? Zijn er hardnekkige problemen, die reiniging en desinfectie lastig maken? (bv. aanwezigheid van Campylobacter, bioflims, of bloedluis) (evt vragen naar cocktail enzymen biofilms)

4. Welke actieve stoffen worden gebruikt voor reiniging en desinfectie van:

a. Stallen (bijv. wanden/vloeren)

b. Materialen in de stal

c. Transportkratten/transportmaterialen

d. Medewerkers (bijv. handen)

e. Slachterij, uitsnijderij, koel- en vrieshuis (vloeren/wanden)

f. Materialen in de slachterij/uitsnijderij/koel- en vrieshuis die in aanraking komen met het voeding:

5. Zou u aan kunnen geven welke concentraties meestal worden gebruikt bij de aangegeven actieve stoffen?

6. Hoe vaak wordt er met deze middelen schoongemaakt of gedesinfecteerd?

7. Welke actieve ingrediënten voor reiniging en desinfectie kunnen een potentieel gevaar opleveren volksgezondheid indien residuen in het product terechtkomen (bv. Door de productie van bijprodı

8. Hoe wordt het juiste gebruik van de middelen geborgd?

a. Wordt er altijd gereinigd voor desinfectie? Zo nee, wanneer niet?

b. Wordt er altijd gespoeld na reiniging of desinfectie? Zo nee, wanneer niet?

c. Hoe wordt ervoor gezorgd dat de minimale inwerkingsduur aangehouden wordt?

d. Hoe wordt ervoor gezorgd dat de juiste concentratie toegepast wordt?

e. Hoe wordt ervoor gezorgd dat de juiste middelen voor de juiste toepassing gebruikt worden?

f. Hoe wordt voorkomen dat niet-toegelaten stoffen gebruikt worden?

g. Zijn er procedures om het reinigen of desinfecteren te controleren? Hoe gaat dit in zijn werk?

h. Waar haalt $u$ informatie vandaan over reiniging en desinfectie op uw bedrijf? Heeft u behoefte aal informatie?

9. Wordt decontaminatie van roodvlees toegepast?

Wat is toegestaan? Welke middelen worden hiervoor gebruikt? 


\title{
Annex 3 Questionnaire inspectors
}

\author{
WAGENINGEN
}

UNIVERSITY \& RESEARCH

\section{Vragenlijst - Reiniging \& desinfectie in de roodvleesketen}

Voor welke schakel in de roodvleesketen vult u deze vragenlijst in?

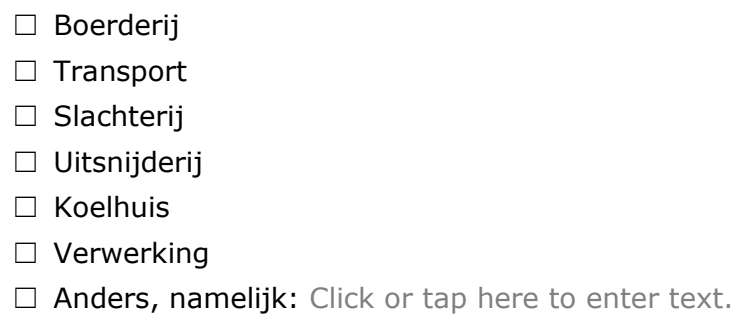

1. Welke actieve stoffen worden gebruikt voor reiniging en desinfectie van:

a. Medewerkers (bijv. handen) Click or tap here to enter text.

b. Vloeren en/of wanden van de boerderij, slachterij, uitsnijderij, koel- en vriesh Click or tap here to enter text.

c. Materialen in/op de boerderij, slachterij, uitsnijderij, koel- en vrieshuis die in komen met het voedingsproduct Click or tap here to enter text.

2. Hoe vaak wordt er met deze middelen schoongemaakt of gedesinfecteerd? Click or tap here to enter text.

3. Welke actieve ingrediënten voor reiniging en desinfectie kunnen een potentieel gevaaı voor de volksgezondheid indien residuen in het product terechtkomen (bv. de product bijproducten)?

Click or tap here to enter text.

4. Hoe wordt het juiste gebruik van de middelen geborgd?

a. Wordt er altijd gereinigd voor desinfectie? Zo nee, wanneer niet? Click or tap enter text.

b. Wordt er altijd gespoeld na reiniging of desinfectie? Zo nee, wanneer niet? Cli here to enter text.

c. Hoe wordt ervoor gezorgd dat de minimale inwerkingsduur aangehouden wor tap here to enter text.

d. Hoe wordt ervoor gezorgd dat de juiste concentratie toegepast wordt? Click o to enter text.

e. Hoe wordt ervoor gezorgd dat de juiste middelen voor de juiste toepassing g€ worden? Click or tap here to enter text.

f. Hoe wordt voorkomen dat niet-toegelaten stoffen gebruikt worden? Click or ti enter text.

g. Zijn er procedures om het reinigen of desinfecteren te controleren? Hoe gaat werk? Click or tap here to enter text.

5. Wordt decontaminatie van roodvlees toegepast?

Wat is toegestaan? Welke middelen worden hiervoor gebruikt? 


\title{
Annex 4 Interviews game meat chain
}

\author{
WAGENINGEN
}

UNIVERSITY \& RESEARCH

\section{Interview Reiniging \& desinfectie in de wildvleesketen}

1. Kunt u wat meer vertellen over uw bedrijf/organisatie?

2. Voor welke schakel in de wildvleesketen kunt u de vragen beantwoorden?

\author{
$\square$ Boerderij \\ $\square$ Jager \\ $\square$ Transport \\ $\square$ Slachterij \\ $\square$ Uitsnijderij \\ $\square$ Koelhuis \\ $\square$ Verwerking \\ $\square$ Anders, namelijk: Click or tap here to enter text.
}

Voor $\square$ gekweekt wild of $\square$ vrij wild?

3. Wat is de belangrijkste reden om schoon te maken of te desinfecteren? Zijn er hardnekkige problemen, die reiniging en desinfectie lastig maken?

4. Welke actieve stoffen worden gebruikt voor reiniging en desinfectie van:

a. Stallen (bijv. wanden/vloeren)

b. Materialen in de stal

c. Materialen bij het jagen

d. Transportkratten/transportmaterialen

e. Medewerkers (bijv. handen)

f. Slachterij, uitsnijderij, koel- en vrieshuis (vloeren/wanden)

g. Materialen in de slachterij/uitsnijderij/koel- en vrieshuis die in aanraking komen met het voeding!

5. Zou u aan kunnen geven welke concentraties meestal worden gebruikt bij de aangegeven actieve stoffen?

6. Hoe vaak wordt er met deze middelen schoongemaakt of gedesinfecteerd?

7. Zijn er verschillen in reiniging en desinfectie bij gekweekt en vrij wild?

8. Welke actieve ingrediënten voor reiniging en desinfectie kunnen een potentieel gevaar opleveren volksgezondheid indien residuen in het product terechtkomen (bv. Door de productie van bijprodı

9. Hoe wordt het juiste gebruik van de middelen geborgd?

a. Wordt er altijd gereinigd voor desinfectie? Zo nee, wanneer niet?

b. Wordt er altijd gespoeld na reiniging of desinfectie? Zo nee, wanneer niet?

c. Hoe wordt ervoor gezorgd dat de minimale inwerkingsduur aangehouden wordt?

d. Hoe wordt ervoor gezorgd dat de juiste concentratie toegepast wordt?

e. Hoe wordt ervoor gezorgd dat de juiste middelen voor de juiste toepassing gebruikt worden?

f. Hoe wordt voorkomen dat niet-toegelaten stoffen gebruikt worden?

g. Zijn er procedures om het reinigen of desinfecteren te controleren? Hoe gaat dit in zijn werk? 


\section{Annex 5 Statement of game hygiene for large game animals}

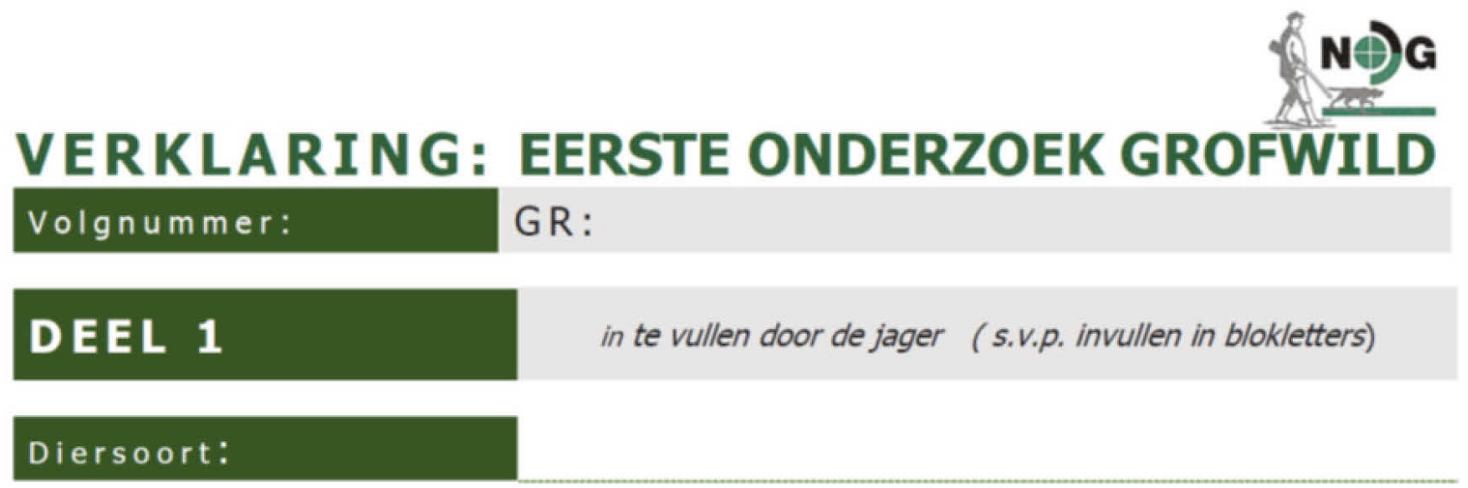

Na am WBE:

Wildmerknr:

Datum afschot

20

Geen bijzonderheden

Bijzonderheden:

(Aankruisen wat van toepassing is) en (ruimte voor opmerkingen m.b.t. bijzonderheden)

Naam Jager

Handtekening Jager

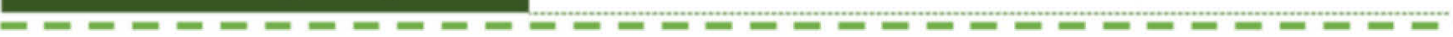

\section{DEEL 2} in te vullen door gekwalificeerd persoon (s.v.p. invullen in blokletters)

\section{Datum onderzoek:}

Plaats onderzoek:

$$
\text { (aankruisen wat van toepassing is) }
$$

Geen abnormaliteiten $\square$ Abnormaliteiten:

Omschrijving abnormaliteiten

Naam gekwalificeerd

persoon:

Certificaatnum mer

Handtekening:

www.nvwa.nl I www.nojg.nl 
Wageningen Food Safety Research

P.O. Box 230

6700 AE Wageningen

The Netherlands

T +31 (0)317480256

www.wur.eu/food-safety-research

WFSR report 2020.021
The mission of Wageningen University \& Research is "To explore the potential of nature to improve the quality of life". Under the banner Wageningen University \& Research, Wageningen University and the specialised research institutes of the Wageningen Research Foundation have joined forces in contributing to finding solutions to important questions in the domain of healthy food and living environment. With its roughly 30 branches, 6,500 employees (5,500 fte) and 12,500 students, Wageningen University \& Research is one of the leading organisations in its domain. The unique Wageningen approach lies in its integrated approach to issues and the collaboration between different disciplines. 



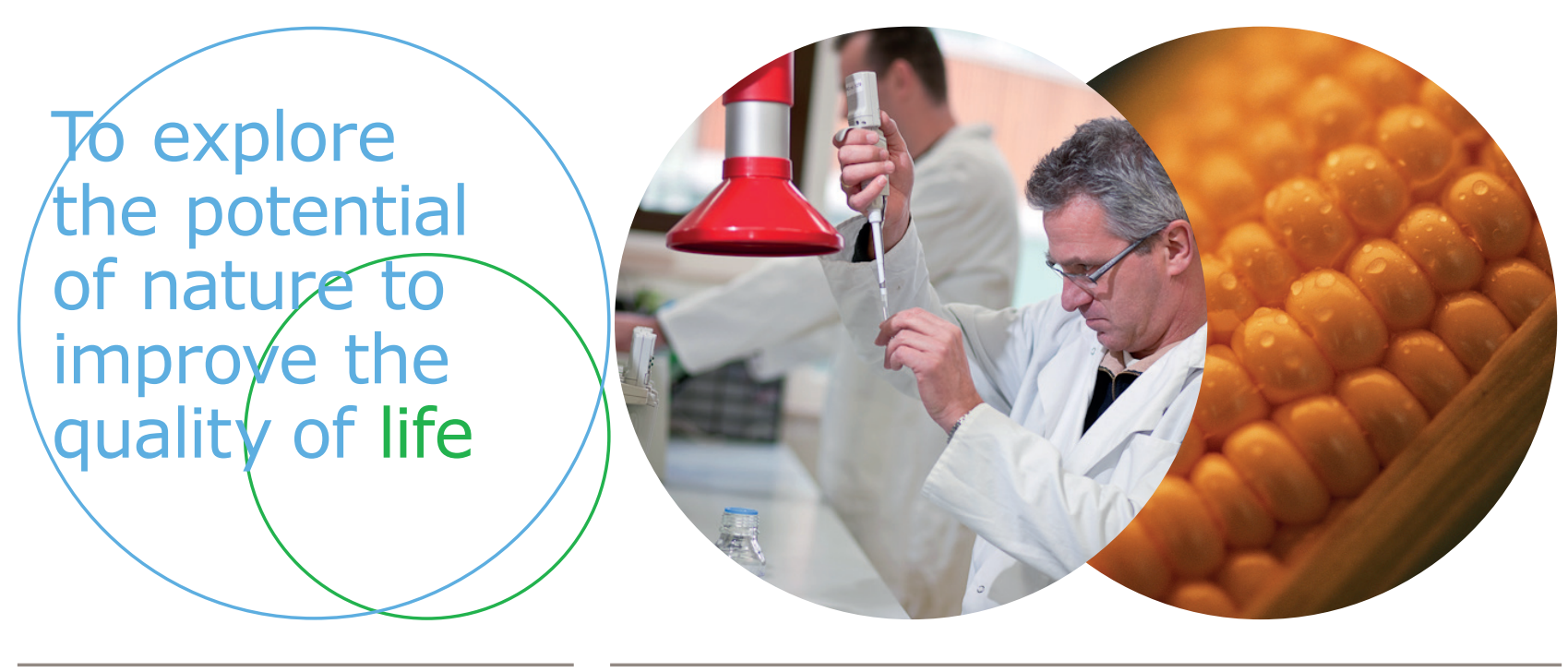

Wageningen Food Safety Research P.O. Box 230

6700 AE Wageningen

The Netherlands

T +31 (0)317480256

www.wur.eu/food-safety-research

WFSR report 2020.021
The mission of Wageningen University \& Research is "To explore the potential of nature to improve the quality of life". Under the banner Wageningen University $\&$ Research, Wageningen University and the specialised research institutes of the Wageningen Research Foundation have joined forces in contributing to inding solutions to important questions in the domain of healthy food and living environment. With its roughly 30 branches, 6,500 employees (5,500 fte) and 12,500 students, Wageningen University \& Research is one of the leading organisations in its domain. The unique Wageningen approach lies in its integrated approach to issues and the collaboration between different disciplines. 